NBER WORKING PAPER SERIES

\title{
MACROECONOMIC INTERDEPENDENCE OF JAPAN AND THE UNITED STATES: SOME SIMULATION RESULTS
}

Naoko Ishii

Warwick McKibbin Jeffrey Sachs

Working Paper No. 1637

\author{
NATIONAL BUREAU OF ECONOMIC RESEARCH \\ 1050 Massachusetts Avenue \\ Cambridge, MA 02138 \\ June 1985
}

We would like to thank the U.S.-Japan Program at Harvard for generous support, and the NBER, and DRI for assistance in preparation of this study. We also thank Mr. Heizo Takenaka for helpful discussions and advice. Warwick McKibbin thanks the Reserve Bank of Australia for financial support. The research reported here is part of the NBER's research program in Economic Fluctuations and International Studies. Any opinions expressed are those of the authors and not those of the National Bureau of Economic Research. 
NBER Working Paper \#1637 June 1985

\section{Macroeconomic Interdependence of Japan and the United States: \\ Some Simulation Results}

\section{ABSTRACT}

In this paper we examine the macroeconomic interdependence of Japan and the U.S. using a medium-scale simulation model of the world economy. Our goal is to determine how shifts in macroeconomic policies in the U.S. or Japan affect the other country as well as the rest of the world. In particular we examine the following three issues: (1) the likely macroeconomic ramifications for the U.S., Europe and Japan of significant budget cuts in the U.S.; (2) the macroeconomic implications of a protectionist tariff imposed by the U.S.; and (3) the scope for policy coordination among the U.S., Japan and Europe.

Naoko Ishii Warwick McKibbin Jeffrey Sachs Department of Economics Harvard University Cambridge, MA 02138 (617) $495-4112$ 


\section{INTRODUCTION}

The macroeconomic linkages between the Japan and the U.S. have become a focus of attention in the policy discussions in both countries. Largely as the result of divergent macroeconomic policies in recent years, the bilateral trade balance between Japan and the U.S. reached an astounding $\$ 37$ billion surplus for Japan in 1984. This trade imbalance has fueled protectionist sentiment in the U.S., with the real possibility that restrictive trade measures will be passed by Congress this year.

Against this backdrop, it is timely to examine the macroeconomic interdependence of the two countries, with a particular goal of determining how shifts in macroeconomic policies in the U.S. and Japan could contribute to continued growth, moderate inflation, and a less extreme trade imbalance between the two countries. What are the likely ramifications for the U.S., Europe, and Japan, of significant budget cuts in the U.S.? What happens as the U.S. economy slows, and therefore stops being the engine of growth for the rest of the world economy? How much would Japan have to compensate via fiscal expansion for a cut in the U.S. budget stimulus? What would be the macroeconomic implications of a protectionist tariff imposed by the U.S.? Finally, what is the scope for policy coordination among the U.S., Japan, and Europe, for optimal adjustments from the current situation?

To answer these questions, we employ a medium-scale simulation model of the world economy, developed earlier by Sachs and McKibbin (1985). In Section II, we offer a brief discussion of the structure and parameterization of the model. In Section III, we explore the macroeconomic effects of various policies undertaken by the U.S., Japan, and OECD. In Section IV we compare various 
policy scenarios for the next 5 years, and describe their macroeconomic implications. Finally, in Section $V$, we present a formal analysis of the gain to policy coordination in the current macroeconomic setting.

II. THE SIMULATION MODEL

\section{A. Theoretical Framework}

The model used in this paper was originally developed in Sachs and McKibbin (1985). Since the particular aim in that work was to study the effect of OECD macroeconomic policies on developing countries, the model divided the world economy into four regions: the U.S., the rest of the OECD (hereafter ROECD), OPEC and the Non-oil Developing countries. In order to examine the interdependence of the U.S. and Japan, we now expand the model to five regions by extracting Japan from the ROECD region. A detailed description of the theoretical framework of the model can be found in Sachs and McKibbin (1985) and further applications can be found in Sachs (1985). The basic structure of the model is not changed by adding Japan and so we concentrate in our discussion on the new Japanese module of the model.

Regions are linked through trade and asset markets. Each region consumes the outputs of other regions, and the regions accumulate assets of other regions through current account imbalances and portfolio shifts. These transactions are summarized in a trade matrix and an asset matrix. Below we show briefly how these two matrices are derived.

Each region produces a single output and consumes that output as well as the outputs of other regions. The trade matrix linking the five regions is 
given in Table 1. The notation $C_{j}^{i}$ signifies the quantity of consumption by country $i$ of the output of country $j$.

Table 1: Trade Matrix

\begin{tabular}{|c|c|c|c|c|c|}
\hline & \multicolumn{5}{|c|}{ Exports to: } \\
\hline & U.S. & Japan & ROECD & LDC & OPEC \\
\hline Exports from: & & & & & \\
\hline U.S. & -- & $C_{U}^{J}$ & $c_{U}^{0}$ & $C_{U}^{L}$ & $c_{U}^{P}$ \\
\hline Japan & $\mathrm{C}_{\mathrm{J}}^{\mathrm{U}}$ & -- & $\mathrm{C}_{\mathrm{J}}^{\mathrm{O}}$ & $C_{J}^{L}$ & $\mathrm{C}_{\mathrm{J}}^{\mathrm{P}}$ \\
\hline ROECD & $\mathrm{C}_{\mathrm{O}}^{\mathrm{U}}$ & $C_{0}^{J}$ & -- & $c_{0}^{L}$ & $\begin{array}{c}C^{P} \\
0\end{array}$ \\
\hline LDC & $\mathrm{C}_{\mathrm{L}}^{\mathrm{U}}$ & $C_{L}^{J}$ & $C_{L}^{0}$ & -- & $\mathrm{C}_{\mathrm{L}}^{\mathrm{P}}$ \\
\hline OPEC & $C_{P}^{U}$ & $C_{P}^{J}$ & $\mathrm{C}_{\mathrm{P}}^{\mathrm{O}}$ & $C_{P}^{L}$ & - \\
\hline
\end{tabular}

Japan is assumed to have essentially the same internal macroeconomic structure as the U.S. and ROECD. Aggregate demand is the sum of private domestic absorption $\left(D^{J}\right)$, exports net of imports, and government spending $\left(G^{J}\right)$. Note that private absorption expenditure includes both consumption and investment demand. Henceforth, $\mathrm{P}^{\mathrm{J}}, \mathrm{P}^{\mathrm{O}}$ are the output prices of Japan and ROECD in the local currencies (yen and ECU, respectively). $\mathrm{E}^{\mathrm{J}}$, and $\mathrm{E}^{\mathrm{O}}$ are the nominal exchange rates, in $\$ /$ yen and $\$ / E C U$. We define the U.S. real exchange rate vis-a-vis Japan and ROECD as $\Lambda^{J}=\left(\mathrm{P}^{\mathrm{J}} \mathrm{E}^{\mathrm{J}} / \mathrm{P}^{\mathrm{U}}\right)$ and $\Lambda^{0}=\left(\mathrm{P}^{\mathrm{O}} \mathrm{E}^{\mathrm{O}} / \mathrm{P}^{\mathrm{U}}\right)$, respectively. Aggregate demand in Japan is written as:

$$
Q^{J}=D^{J}+G^{J}+\left(C_{J}^{U}+C_{J}^{O}+C_{J}^{L}+C_{J}^{P}\right)-\left(C_{U}^{J}+\Lambda C_{O}^{J}+\Lambda C_{L}^{J}+\Lambda C_{P}^{J}\right) / \Lambda
$$


Private absorption is written as a linear function of GDP net of total taxes $T$, the real interest rate $r$, and the financial wealth, $H$

$$
D^{J}=\left(1-S^{J}\right)\left(Q^{J}-T^{J}\right)-\nu r^{J}+\delta H^{J}
$$

Note that we will assume that Japan has a relatively high saving rate ( $\mathrm{S}^{\mathrm{J}}$ ) compared with the U.S. and ROECD.

The import demands are specified as proportional to national absorption $\left(D^{J}+G^{J}\right)$, and as a negative function of the relative import price:

$$
\begin{aligned}
& C_{U}^{J}=\alpha_{4}\left(D^{J}+G^{J}\right)\left(\Lambda^{J}\right)^{1.5} \\
& C_{O}^{J}=\alpha_{5}\left(D^{J}+G^{J}\right)\left(\Lambda^{O} / \Lambda^{J}\right)^{-1.5} \\
& C_{L}^{J}=\alpha_{6}\left(D^{J}+G^{J}\right)\left(\Lambda^{L} / \Lambda^{J}\right)^{-1.0} \\
& C_{P}^{J}=\alpha_{7}\left(D^{J}+G^{J}\right)\left(\Lambda^{P} / \Lambda^{J}\right)^{-0.2}
\end{aligned}
$$

Consumer prices are a geometric weighted average of domestic and foreign prices, with weights equal to initial expenditure shares.

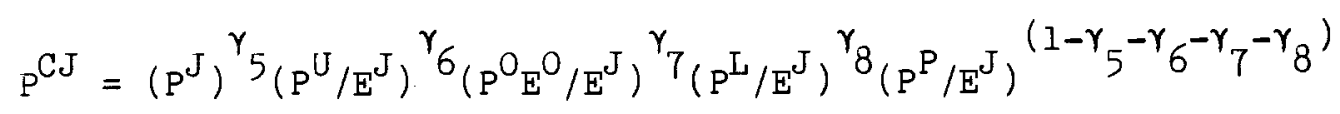

Let $\pi_{t+1}^{J}$ denote $\left(P_{t+1}^{J}-P_{t}^{J}\right) / P_{t}^{J}$, and $\pi_{t+1}^{C J}$ denote the CPI inflation $\left(P_{t+1}^{C J}-P_{t}^{C J}\right) / P_{t}^{C J}$. We assume that the the nominal wage is predetermined in period $t$ (that is, contemporaneous shocks do not affect the current wage). The change in the wage from period $t$ to period $t+1$ is a function of $\pi_{t}^{C J}, Q_{t}^{J}$, and the change in $Q_{t}^{J}$. Then, by assumption of a fixed price markup over wages, we have:

$$
\pi_{t+1}^{J}=\pi_{t}^{C J}+3 Q_{t}^{J}+\tau\left(Q_{t}^{J}-Q_{t-1}^{J}\right)
$$

This equation says that current domestic inflation $\left(\pi_{t+1}^{J}\right)$ is a function of 
lagged consumer price inflation ( $\left.\begin{array}{c}\mathrm{CJ} \\ t\end{array}\right)$, lagged GDP relative to potential $\left(Q_{t}^{J}\right)$, and the change in lagged GDP relative to potential $\left(Q_{t}^{J}-Q_{t-1}^{J}\right)$.

The money demand equation is written in standard transactions demand form:

$$
M^{J} / P^{J}=\left(Q^{J}\right)^{\dot{P}}\left(1+i^{J}\right)^{-\hat{\theta}}
$$

Here, the nominal interest $i_{t}^{J}$ equals $r_{t}^{J}+\left(P_{t+1}^{J}-P_{t}^{J}\right) / P_{t}^{J}$, where $r_{t}^{J}$ is the real interest rate.

Now let us move to another important feature in the structure of this model, namely the asset holding matrix. We make strong assumptions about portfolio holdings to simplify the model. Japanese and ROECD residents hold U.S. assets, while U.S. residents do not hold Japanese and ROECD assets. Mutual asset holdings between Japan and ROECD are also ignored to avoid more complexity. Japanese residents hold: J.S. \$-denominated claims on U.S. residents $\left(A_{U}^{J}\right)$, Japanese yen-denominated government bonds $\left(B^{J}\right)$, and claims on the LDC's, which are divided into yen-denominated $\left(A_{L J}^{J}\right)$ and U.S. \$-denominated claims $\left(A_{L U}^{J}\right)$. The Japanese government holds official claims on the LDC's ( $B_{L}^{J}$ ) which are yen-denominated and issued at concessional rates $\left(v_{t}^{J}\right)$. Table 2 shows the matrix of asset holding. The wealth of Japanese residents is then

$$
\mathrm{H}^{\mathrm{J}}=\mathrm{B}^{\mathrm{J}}+\mathrm{A}_{\mathrm{J}}^{\mathrm{J}} / \mathrm{L}^{\mathrm{J}}+\mathrm{A}_{\mathrm{LJ}}^{\mathrm{J}}+\mathrm{A}_{\mathrm{LU}}^{\mathrm{J}} / \mathrm{L}^{\mathrm{J}}-\mathrm{A}_{\mathrm{J}}^{\mathrm{P}}
$$

The change in Japanese government bonds $\left(B^{J}\right)$ is related to the fiscal deficit $\left(\mathrm{DEF}^{\mathrm{J}}\right)$ as follows:

$$
\begin{aligned}
& D E F^{J}=G^{J}+r^{J} B^{J}-T^{J}-v^{J} B_{L}^{J} \\
& B_{t+1}^{J}=\left(B_{t}^{J}+D E F_{t}^{J}\right) /(1+n)
\end{aligned}
$$

The term $(1+n)$ arises since $B$ is measured relative to potential GDP, which grows 
at the rate $n$.

The asset matrix, in full, is given as follows ("P" signifies private sector, and "O" signifies official, or public, sector):

Table 2. Asset Holding Matrix

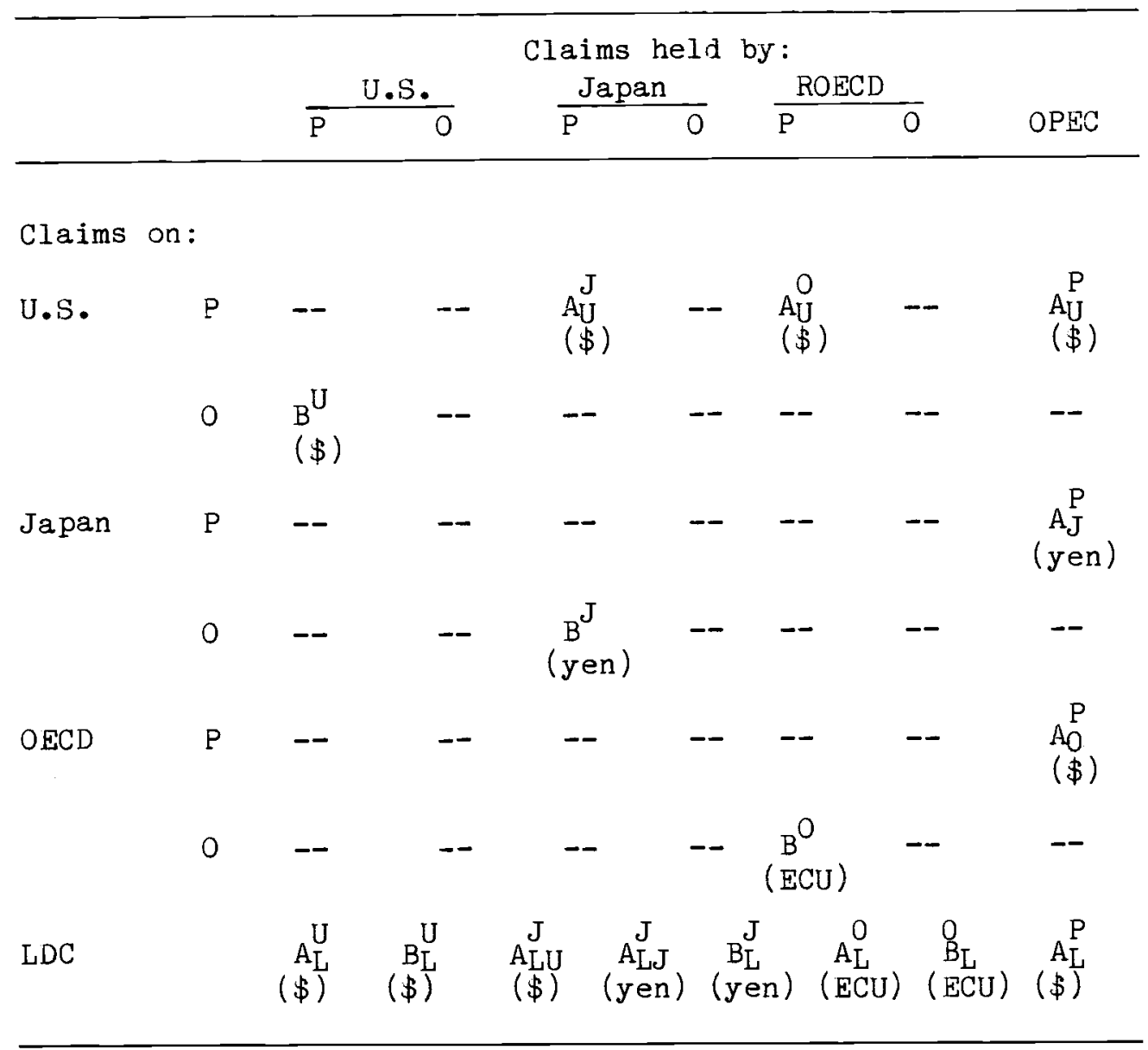

Next we use asset market equilibrium conditions to determine the

exchange rate. We assume that $\$$-denominated assets and yen-denominated assets are imperfect substitutes in the Japanese portfolio, and that Japanese private wealth (equation $(7))$ is divided between net yen assets $\left(B^{J}+A_{L J}^{J}-A_{J}^{P}\right.$ ) and dollar assets $\left(A_{U}^{J}+A_{L U}\right) / R^{J}$, based on relative asset returns. The return differential is $i_{t}^{u}-i_{t}^{J}-\left(E_{t+1}^{J}-E_{t}^{J}\right) / E_{t}^{J}$ 
or, equivalently,

$$
r_{t}^{U}-r_{t}^{J}-\left(\Lambda_{t+1}^{J}-\Lambda_{t}^{J}\right) / \Lambda_{t}^{J}
$$

Note that the first expression gives the nominal interest rate differential adjusted for nominal exchange rate changes, while the second expression shows the real interest rate differential adjusted for real exchange rate changes (of course, the two expressions are equivalent). The asset market equation gives the net dollar asset demand as

$$
\left(A_{U t}^{J}+A_{L U t}^{J}\right) / \Lambda_{t}^{J}=\sigma^{J}\left[r_{t}^{u}-r_{t}^{J}-\left(\Lambda_{t+1}^{J}-\Lambda{ }_{t}^{J}\right) / \Lambda_{t}^{J}\right]+\theta H_{t}^{J}
$$

$\theta$ is the marginal propensity to hold $\$$ assets out of Japanese financial wealth, and $\sigma^{J}$ is the degree of asset substitutability between $\$$ and yen assets. Let $C A^{J}$ be the real dollar value of the Japanese current account:

$$
\begin{aligned}
C A & =\Lambda\left(C_{J}^{U}+C_{J}^{O}+C_{J}^{L}+C_{J}^{P}\right)-\left(C_{U}^{J}+\Lambda C_{O}^{J}+\Lambda C_{L}^{J}+\Lambda C_{P}^{J}\right)+r\left(A_{U}^{J}+A_{L U}^{J}\right) \\
& +r\left(A_{L J}^{J}-A_{J}^{P}\right) \Lambda+{ }^{J} B_{L}^{J} \Lambda
\end{aligned}
$$

The current account is financed multilaterally, by changes in $A_{U}^{J}, A_{L U}^{J}$, $A_{L J}^{J}, A_{J}^{P}$ and $B_{L}^{J}$ :

$$
\begin{aligned}
C A_{t}^{J} & =\left[(1+n) A_{U t+1}^{J}-A_{U t}^{J}\right] \\
& +\left[(1+n)\left(A_{L J t+1}^{J} \Lambda_{t}^{J}+A_{L U t+1}^{J}+B{ }_{L t+1}^{J} \Lambda_{t}^{J}\right)-\left(A_{L J t}^{J} \Lambda_{t}^{J}+A_{L U t}^{J}+B_{L t}^{J} \Lambda_{t}^{J}\right)\right] \\
& -\left[(1+n) A_{J t+1}^{P} \Lambda_{t}^{J}-A_{J t}^{P} \Lambda_{t}^{J}\right]
\end{aligned}
$$

To derive an equation for the evolution of Japanese holdings of U.S. assets (12) is rewritten as: 
$\left(12^{\prime}\right)$

$$
\begin{aligned}
A_{U t+1}^{J} & =\left(A_{U t}^{J}+C A_{t}^{J}\right) /(1+n)-\left[\left(A_{L J t+1}^{J} \Lambda_{t}^{J}+A_{L U t+1}^{J}+B_{L t+1}^{J} \Lambda_{t}^{J}-A_{J t+1}^{P} \Lambda_{t}^{J}\right)\right. \\
& \left.-\left(A_{L J t}^{J} \Lambda_{t}^{J}+A_{L U t}^{J}+B_{L t}^{J} \Lambda_{t}^{J}-A_{J t}^{P} \Lambda_{t}^{J}\right) /(1+n)\right]
\end{aligned}
$$

Changes in other asset holding are determined by assuming that initial asset shares are maintained in the new steady state.

The remaining part of the model contains the foreign trade and finance of OPEC and the LDCs. Japan is assumed to behave in the same way as the U.S. and ROECD vis-a-vis OPEC and the LDCs in our model. We refer the reader to the detailed discussion in Sachs and McKibbin (1985).

B. Numerical Parameterization and Simulation Methodology

The entire model is set forth in Appendix 1. In scaling the model, coefficients for structural equations, trade and expenditure shares, and initial asset stocks are required. Japan is treated as having the same basic structure as the U.S. and OECD in aggregate demand, pricing, and money demand. The major differences between them are in the composition and direction of trade and in portfolio preferences. Besides these differences, a few of the key assumed parameter values (shown in Appendix 1) for Japan are specified differently: the saving rate for Japan is set higher than those of the U.S. and ROECD; the parameter for substitutability of Yen and Dollar assets is set at 1 whereas for ECU and Dollar assets is set at 4.0. This implies that ECU and Dollar assets are closer substitutes than Yen and Dollar assets.

The direction and composition of trade is shown in Table 3 , based on the 1983 trade data of the IMF Direction of Trade Statistics. A detailed 
$-9-$

Table 3: Trade Matrix, 1983*

(\$ billion)

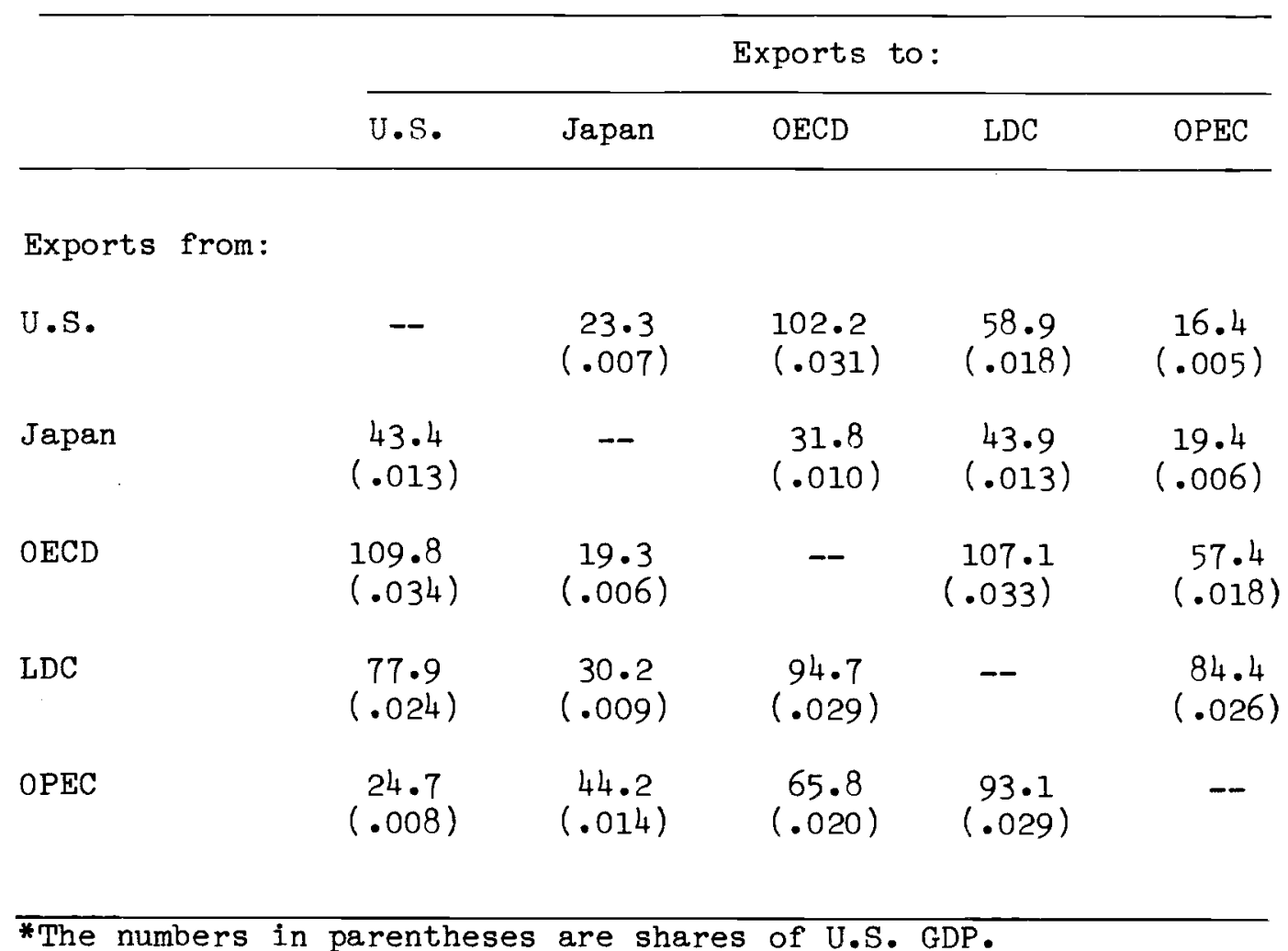


description of its derivation is provided in Sachs and McKibbin (1985). The data on initial asset holding is required when we linearize the model around an initial equilibrium (based on 1983 data). The assumed asset matrix is shown in Table 4. The data available for our work is rather limited and the procedures to derive the matrix are sufficiently complicated that we only mention key factors here. A detailed explanation about the general procedure is described in the Sachs and McKibbin (1985) and specific details are also available from the authors upon request. The data sources are: IMF World Economic Outlook, World Debt Tables, World Bank; Economic Report of the President; Japanese Ministry of Finance; the Bank of Japan; and Mattione (1983).

III. MODEL SIMULATIONS: POLICY CHANGES AND OIL PRICE SHOCK

In this section we use the model to examine the effects of fiscal and monetary policies in the U.S. and Japan on world macroeconomic equilibrium. We also consider the effects of an increase in tariffs on U.S. imports of Japanese goods and a retaliatory Japanese tariff on imports of U.S. goods. Finally, in this section we consider the impact of an oil price shock in our model.

Tables 5-11 show the various effects of these policies. Note that in these tables "\%" signifies percentage deviation from the initial baseline; "d" signifies the level deviation from the initial baseline; and "\$bl" signifies deviation from the initial baseline in 1984 constant U.S. dollars. 
Table 4: Portfolio Matrix

(Ratio of Net Asset Holding to U.S. GDP)

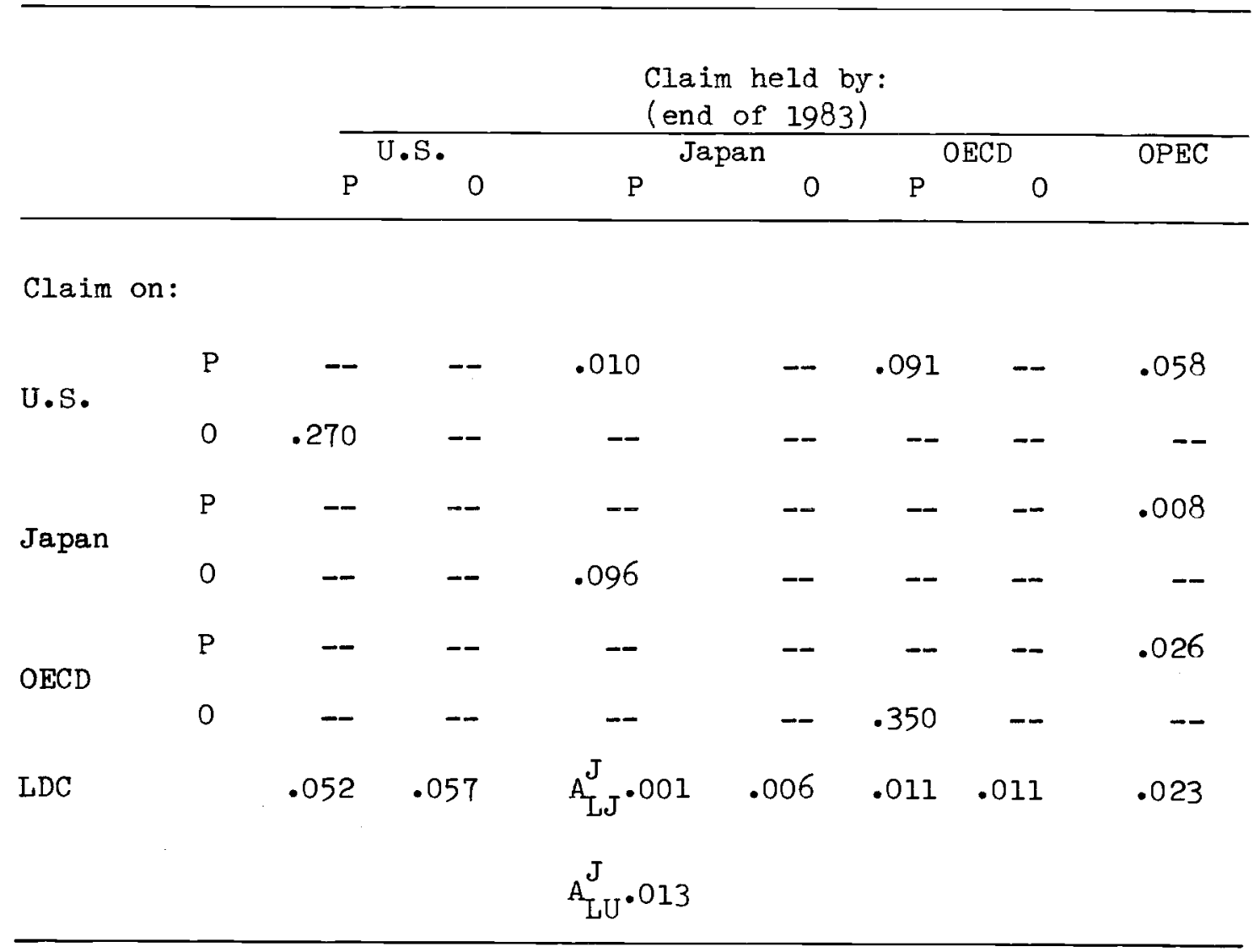


A. Fiscal Expansion (U.S. and Japan)

The change in fiscal policy we consider is a sustained $1 \%$ of GNP increase in real government expenditure commencing in 1984, with no initial change in taxes. Over time taxes are raised in line with the debt service payments in order to keep the government budget deficit constant at $1 \%$ of GNP.

The results for a U.S. fiscal expansion are shown in Table 5. The fiscal stimulus increases U.S. GIN by $1.0 \%$ in the first year and $1.1 \%$ in the second year. However this expansionary effect is not sustained as rising interest rates, higher prices, and a strong dollar increasingly crowd out the fiscal stimulus. Inflation initially falls by .3 percent in the U.S., due to the exchange rate appreciation (against both yen and ECU) and the initial sluggishness of domestic prices. However inflation rises in 1985 and after, as rising domestic prices resulting from increased domestic demand (via the Phillips curve) dominate the deflationary effects of a strong dollar.

The Japanese and ROECD economies gain in terms of GNP from the U.S. fiscal expansion. Trade balances in both regions improve and provide a stimulus to domestic output although the movement of capital into the U.S. (and away from Japan and ROECD), which is attracted by rising U.S. interest rates, raises interest rates in both Japan and ROECD. This tends to limit the output gains.

These results may, in fact, underestimate the effects on bilateral trade between the U.S. and Japan. We have experimented with the price elasticity of U.S. imports from Japan and found that an increase in this elasticity from 1.5 to 2.5 enlargens the fall in U.S. net exports to Japan from $\$ 2.9 \mathrm{bl}$ to $\$ 3.8 \mathrm{bl}$. 


\begin{tabular}{llll}
\hline & 1984 & 1985 & 1986 \\
\hline
\end{tabular}

U.S. Economy:

\begin{tabular}{|c|c|c|c|c|c|}
\hline $\begin{array}{ll}\text { GNP } & (\$ 84) \\
\operatorname{GNP} & (\$ 84)\end{array}$ & $\begin{array}{l}\% \\
\$ \mathrm{bl}\end{array}$ & $\begin{array}{r}1.0 \\
35.1\end{array}$ & $\begin{array}{r}1.1 \\
40.8\end{array}$ & $\begin{array}{r}0.9 \\
36.5\end{array}$ & $\begin{array}{r}0.6 \\
24.3\end{array}$ \\
\hline Inflation & $\mathrm{D}$ & -0.3 & 0.2 & 0.4 & 0.6 \\
\hline Interest rate & $\mathrm{D}$ & 0.9 & 1.1 & 1.4 & 1.8 \\
\hline Exchange rate $(\mathrm{Ecu} / \$)$ & $\%$ & 4.0 & $3 \cdot 9$ & 3.8 & $3 \cdot 7$ \\
\hline Trade balance $(\$ 84)$ & $\$ b l$ & -15.6 & $-15 \cdot 5$ & $-15 \cdot 9$ & -16.4 \\
\hline U.S. current a/c (\$) & $\$ b 1$ & -18.1 & -18.9 & $-21 \cdot 2$ & $-24 \cdot 0$ \\
\hline
\end{tabular}

Japanese Economy:

$\begin{array}{lccccc}\text { GNP } & \% & 0.6 & 0.4 & 0.2 & 0.0 \\ \text { Inflation } & D & 0.1 & 0.4 & 0.4 & 0.4 \\ \text { Interest rate } & D & 0.6 & 0.8 & 1.1 & 1.3 \\ \text { Exchange rate }(Y e n / \$) & D & 3.6 & 3.3 & 3.1 & 3.0 \\ \text { Trade balance }(\$ 84) & \% & 3.6 & 3.1 & 2.7 & 2.5 \\ \text { Japan current } \mathrm{a} / \mathrm{c}(\$) & \$ b 1 & 4.2 & 4.0 & 4.1 & 4.4\end{array}$

OECD Economies:

GNP

$\begin{array}{lllll}\% & 0.8 & 0.5 & 0.2 & -0.2\end{array}$

Inflation

$\begin{array}{lllll}\text { D } & 0.2 & 0.5 & 0.5 & 0.4\end{array}$

$\begin{array}{llllll}\text { Interest rate } & D & 0.7 & 1.0 & 1.2 & 1.5\end{array}$

$\begin{array}{llllll}\text { Trade balance }(\$ 84) & \$ b 1 & 14.2 & 13.5 & 13.3 & 13.7\end{array}$

$\begin{array}{lllllll}\text { OECD current a/c }(\$) & \$ b l & 15.9 & 16.5 & 18.8 & 21.6\end{array}$

Bilateral Trade (\% U.S. GNP):

U.S. net exports to Japan

U.S. net exports to OECD

Japan net exports to OECD

$\begin{array}{lrrrr}\% & -0.1 & -0.1 & -0.1 & -0.1 \\ (\$ 84 \mathrm{bl}) & -2.9 & -2.7 & -2.6 & -2.6 \\ \% & -0.3 & -0.3 & -0.3 & -0.3 \\ (\$ 84 \mathrm{bl}) & -10.4 & -10.1 & -10.2 & -10.6 \\ \% & & & & \\ (\$ 84 \mathrm{bl}) & -0.7 & -0.7 & -0.8 & -0.9\end{array}$


The stimulas to Japan from the U.S. fiscal expansion is therefore increased. The case of a Japanese fiscal expansion is shown in Table 6. The Japanese fiscal expansion has qualitatively similar effects on the Japanese economy as the U.S. fiscal expansion has on the U.S. economy. Japanese GNP rise by $0.6 \%$ in the first year. This is less than for the U.S. case because of the assumption of a larger propensity to save in Japan. An interesting point to note is that the Yen appreciates in the case of a Japanese fiscal expansion (as does the U.S. dollar in the case of a U.S. Fiscal expansion). This comes from our assumption of high (but not infinite) asset substituability between Japanese and U.S. assets reflecting the recent move towards liberalization of Japanese financial markets. The importance of this assumption will be discussed further below. The mechanism of adjustment underlying our results is the familiar Mundell/Flemming story: The Japanese fiscal expansion stimulates domestic demand and drives up domestic interest rates. These higher rates attract foreign capital. This increased demand for Japanese assets tends to appreciate the currency even as the trade balance worsens.

Note that the rise in interest rates in the country with the fiscal expansion is greater than in the foreign countries (i.e. an increase in the interest diffential) despite our assumption of high asset substitutability. This is because the fiscal expansion gives rise to expectations of future depreciation of the currency after an initial appreciation. The interest rate differential compensates for the anticipated future depreciation. To a smaller extent, the higher interest rates also reflect a rising risk premium on the assets of the country undertaking the fiscal expansion. 
Table 6: Effects of Japanese Fiscal Expansion

\begin{tabular}{|c|c|c|c|c|c|}
\hline & & 1984 & 1985 & 1986 & 1987 \\
\hline \multicolumn{6}{|l|}{ U.S. Economy: } \\
\hline GNP $(\$ 84)$ & $\%$ & 0.2 & 0.1 & 0.0 & 0.0 \\
\hline GNP $(\$ 84)$ & $\$ \mathrm{bl}$ & $7 \cdot 5$ & 4.6 & 1.6 & -1.8 \\
\hline Inflation & D & 0.1 & 0.1 & 0.2 & 0.1 \\
\hline Interest rate & D & 0.2 & 0.3 & 0.4 & 0.4 \\
\hline Exchange rate $($ Ecu $/ \$)$ & $\%$ & 0.0 & $-0 \cdot 1$ & -0.1 & -0.1 \\
\hline Trade balance $(\$ 84)$ & $\$ \mathrm{bl}$ & $2 \cdot 7$ & 2.9 & $3 \cdot 3$ & 3.7 \\
\hline U.S. current a/c (\$) & $\$ b 1$ & 2.7 & 2.4 & 2.6 & 2.8 \\
\hline \multicolumn{6}{|l|}{ Japanese Economy: } \\
\hline GNP & $\%$ & 0.6 & 0.8 & 0.8 & 0.7 \\
\hline Inflation & $\mathrm{D}$ & -0.3 & 0.0 & 0.2 & 0.4 \\
\hline Interest rate & $\mathrm{D}$ & 0.5 & 0.7 & 0.9 & 1.2 \\
\hline Exchange rate $($ Yen $/ \$)$ & $\%$ & $-3 \cdot 2$ & $-2 \cdot 9$ & -2.8 & -2.7 \\
\hline Trade balance $(\$ 84)$ & $\$ \mathrm{bl}$ & $-5 \cdot 9$ & $-5 \cdot 5$ & $-5 \cdot 5$ & $-5 \cdot 9$ \\
\hline Japan current a/c (\$) & $\$ \mathrm{bl}$ & -6.0 & -5.6 & $-5 \cdot 9$ & $-6 \cdot 5$ \\
\hline \multicolumn{6}{|l|}{ OECD Economies: } \\
\hline GNP & $\%$ & 0.2 & 0.1 & 0.0 & 0.0 \\
\hline Inflation & $\mathrm{D}$ & 0.1 & 0.1 & 0.1 & 0.1 \\
\hline Interest rate & $\mathrm{D}$ & 0.1 & 0.2 & 0.3 & 0.4 \\
\hline Trade balance $(\$ 84)$ & $\$$ bl & 2.8 & 3.2 & $3 \cdot 7$ & 4.0 \\
\hline OECD current a/c $(\$)$ & $\$ \mathrm{bl}$ & $2 \cdot 9$ & $4 \cdot 2$ & 5.2 & 6.0 \\
\hline \multicolumn{6}{|l|}{ Bilateral Trade (\% U.S. GNP): } \\
\hline U.S. net exports to Japan & $\%$ & 0.1 & 0.1 & 0.1 & $\begin{array}{l}0.1 \\
2.4\end{array}$ \\
\hline U.S. net exports to $O E C D$ & & 0.0 & 0.0 & 0.0 & \\
\hline & $(\$ 84 \mathrm{bl})$ & 0.0 & 0.1 & 0.1 & 0.2 \\
\hline Japan net exports to OECD & $\begin{array}{l}\% \\
(\$ 84 \mathrm{bl})\end{array}$ & $\begin{array}{r}0.0 \\
-1.8\end{array}$ & $\begin{array}{r}0.0 \\
-1.6\end{array}$ & $\begin{array}{r}0.0 \\
-1.7\end{array}$ & $\begin{array}{r}0.0 \\
-1.8\end{array}$ \\
\hline
\end{tabular}


The cross-country effects of U.S. and Japanese fiscal policy differ mainly because of the relative sizes of the two economies. The sheer size of the U.S. fiscal expansion relative to the Japanese fiscal expansion (Japanese GNP is assumed to be $35 \%$ of U.S. GNP so a fiscal shock of $1 \%$ of Japanese GNP compares to a fiscal shock of . $3 \%$ of U.S. GNP) means that the U.S. has a much larger impact on Japanese GNP than vice versa. Japan gains $.6 \%$ of GNP in the first year following a U.S. fiscal expansion and continues to gain over the first four years. The U.S on the other hand gains only $0.2 \%$ of GNP in the first year of a Japanese expansion, and that effect declines rapidly in the following years.

B. Monetary Expansion (J.S. and Japan)

The results for a sustained increase in money of $1 \%$ commencing in 1984 are shown in Table 7 for the U.S. and Table 8 for Japan. A monetary expansion in either Japan or the U.S. raises GNP in the originating country but has beggar-thy-neighbour consequences for the foreign country in the first year of the shock. A U.S. monetary expansion raises U.S. GNP by $0.9 \%$ in the first year although the stimulus to GNP is dissipated by the fourth year. In Japan the inital rise in GNP from an increase in the Japanese money supply is . $8 \%$ in the first year and, as in the case for the U.S., the stimulus to GNP is eliminated by the fourth year.

The exchange rate provides substantial insulation from the consequences of foreign monetary shocks. In both the U.S. and Japan, the country which initiates the monetary expansion incurs a currency depreciation. This is again the familiar result from a simple Mundell/Flemming model where the monetary 
Table 7: Effects of U.S. Monetary Expansion

\begin{tabular}{|c|c|c|c|c|c|}
\hline & & 1984 & 1985 & 1986 & 1987 \\
\hline \multicolumn{6}{|l|}{ U.S. Economy: } \\
\hline GNP (\$84) & $\%$ & 0.9 & 0.6 & 0.3 & -0.1 \\
\hline GNP $(\$ 84)$ & $\$ \mathrm{bl}$ & $33 \cdot 7$ & $22 \cdot 5$ & $9 \cdot 6$ & $-3 \cdot 0$ \\
\hline Inflation & $\mathrm{D}$ & 0.1 & 0.4 & 0.4 & 0.4 \\
\hline Interest rate & $\mathrm{D}$ & -0.3 & -0.1 & 0.1 & 0.2 \\
\hline Exchange rate $(E c u / \$)$ & $\%$ & -0.8 & -0.6 & -0.6 & -0.6 \\
\hline Trade balance $(\$ 84)$ & $\$ b l$ & 0.2 & $-1 \cdot 1$ & -1.8 & -2.0 \\
\hline U.S. current a/c $(\$)$ & $\$ b l$ & 2.8 & 0.1 & -1.6 & $-2 \cdot 7$ \\
\hline \multicolumn{6}{|l|}{ Japanese Economy: } \\
\hline GNP & $\%$ & -0.1 & 0.0 & 0.1 & 0.1 \\
\hline Inflation & $\mathrm{D}$ & 0.0 & 0.0 & 0.0 & 0.1 \\
\hline Interest rate & D & -0.1 & 0.0 & 0.0 & 0.1 \\
\hline Exchange rate (Yen $/ \$)$ & $\%$ & -0.8 & -0.6 & -0.6 & -0.6 \\
\hline Trade balance $(\$ 84)$ & $\$ b 1$ & -0.2 & 0.3 & 0.5 & 0.6 \\
\hline Japan current a/c $(\$)$ & $\$ b l$ & -0.8 & 0.1 & 0.6 & 0.8 \\
\hline \multicolumn{6}{|l|}{ OECD Economies: } \\
\hline GNP & $\%$ & -0.1 & 0.0 & 0.1 & 0.1 \\
\hline Inflation & $\mathrm{D}$ & 0.0 & 0.0 & 0.0 & 0.1 \\
\hline Interest rate & $\mathrm{D}$ & -0.1 & 0.0 & 0.0 & 0.1 \\
\hline Trade balance $(\$ 84)$ & $\$ b l$ & $-1 \cdot 3$ & 0.5 & 1.7 & 2.2 \\
\hline OECD current a/c $(\$)$ & $\$ \mathrm{bl}$ & $-2 \cdot 9$ & 0.4 & 2.2 & $3 \cdot 2$ \\
\hline \multicolumn{6}{|l|}{ Bilateral Trade ( $\%$ U.S. GNP): } \\
\hline U.S. net exports to Japan & $\stackrel{\%}{(\$ 84 \mathrm{~b} 1)}$ & $\begin{array}{l}0.0 \\
0.1\end{array}$ & $\begin{array}{r}0.0 \\
-0.2\end{array}$ & $\begin{array}{r}0.0 \\
-0.4\end{array}$ & $\begin{array}{r}0.0 \\
-0.4\end{array}$ \\
\hline U.S. net exports to OECD & ${ }^{\%}(\$ 84 \mathrm{bl})$ & $\begin{array}{l}0.0 \\
0.7\end{array}$ & $\begin{array}{r}0.0 \\
-0.4\end{array}$ & $\begin{array}{r}0.0 \\
-1.2\end{array}$ & $\begin{array}{r}0.0 \\
-1.5\end{array}$ \\
\hline Japan net exports to OECD & $\begin{array}{l}\% \\
(\$ 84 \mathrm{bl})\end{array}$ & $\begin{array}{l}0.0 \\
0.1\end{array}$ & $\begin{array}{l}0.0 \\
0.0\end{array}$ & $\begin{array}{l}0.0 \\
0.0\end{array}$ & $\begin{array}{r}0.0 \\
-0.1\end{array}$ \\
\hline
\end{tabular}


Table 8: Effects of Japanese Monetary Expansion

\begin{tabular}{lllll}
\hline & 1984 & 1985 & 1986 & 1987 \\
\hline
\end{tabular}

U.S. Economy:

$$
\text { GNP }(\$ 84)
$$

GNP (\$84)

Inflation

Interest rate

Exchange rate $(\operatorname{Ecu} / \$)$

Trade balance $(\$ 84)$

U.S. current a/c (\$)

Japanese Economy:

$$
\text { GNP }
$$

Inflation

Interest rate

Exchange rate $($ Yen $/ \$)$

Trade balance $(\$ 84)$

Japan current a/c (\$)

OECD Economies:

GNP

Inflation

Interest rate

Trade balance $(\$ 84)$

OECD current a/c ( $\$)$

Bilateral Trade (\% U.S. GNP) :

U.S. net exports to Japan

U.S. net exports to OECD

Japan net exports to OECD

$\begin{array}{lrrrr}\% & 0.0 & 0.0 & 0.0 & 0.1 \\ \$ \mathrm{bl} 1 & -1.7 & 0.4 & 1.9 & 2.3 \\ \mathrm{D} & 0.0 & 0.0 & 0.0 & 0.0 \\ \mathrm{D} & 0.0 & 0.0 & 0.0 & 0.0 \\ \% & 0.0 & 0.0 & 0.0 & 0.0 \\ \$ \mathrm{~b} 1 & -0.5 & -0.2 & 0.2 & 0.4 \\ \$ \mathrm{~b} 1 & -0.7 & -0.1 & 0.2 & 0.4\end{array}$

$\%$

D

D

$\%$

$\$ \mathrm{bl}$

$\$ b 1$

$\%$

D

D

$\$ b 1$

$\$ b 1$

$\begin{array}{lrrrr}\% & 0.0 & 0.0 & 0.0 & 0.0 \\ (\$ 84 \mathrm{~b} 1) & -0.6 & -0.1 & 0.2 & 0.4\end{array}$ $(\$ 84 \mathrm{bl})$ $\begin{array}{ll}\% & 0.0 \\ (\$ 84 \mathrm{~b} 1) & 0.4\end{array}$

0.8

0.4

0.2

0.0

0.1

0.3

$0 \cdot 3$

0.3

D $\quad-0.4$

$-0.3$

$-0.1$

0.0

1.2

0.8

0.6

0.5

0.9

0.0

$-0.6$

$-0.9$

1.1

0.1

$-0.5$

$-0.9$

$\% \quad 0$.

0.0

0.0

0.0

0.0

0.0

0.0

0.0

0.0

0.0

0.0

0.0

0.0

$-0.5$

$-0.2$

0.2

0.5

0.0

0.4

$-0.4$

\section{0}

0.4

$\begin{array}{lllll}\$ 84 \mathrm{~b} 1 & -0.6 & -0.1 & 0.2 & 0.4\end{array}$

$\begin{array}{llllr}\% & 0.0 & 0.0 & 0.0 & 0.0 \\ (\$ 84 \mathrm{bl}) & 0.0 & 0.0 & 0.0 & 0.0 \\ \% & & & & \\ (\$ 84 \mathrm{bl} 1) & 0.0 & 0.0 & 0.0 & 0.0 \\ & 0.4 & 0.1 & -0.2 & -0.3\end{array}$


expansion reduces domestic interest rates, induces a capital outflow and hence results in a depreciation of the currency. In our model this leads to an inflationary impulse in the source country in the first year which is further exacerbated in the second year when wages and domestic prices adjust to the higher import prices and the demand stimulus. The trade balance of the country which initiates the monetary expansion improves initially, but then worsens after the first year, as the increased demand for imports that results from the output expansion dominates the effects on imports and exports from the exchange rate depreciation.

C. Effect of a General Rise in Tariffs

In this section we consider the effect of two changes in the level of tariffs. In the first case, shown in Table 9, the U.S. is assumed to impose an across-the-board tariff increase on imports from Japan of $30 \%$. The tariff is assumed to be neutral with respect to total tax revenues (i.e., tariff revenues are redistributed to the private sector). In the second case, shown in Table 10, we assume the same U.S. policy but with a Japanese response of an across-the-board tariff increase of $30 \%$ on all imports from the U.S. In the case where only the U.S. increases tariffs, U.S. GNP rises in the first three years as domestic residents substitute away from Japanese goods. The Yen depreciates by $12.4 \%$ initially and continues to depreciate as a result of the shift in demand. The bilateral trade balance between the U.S. and Japan improves from the U.S. standpoint by $\$ 14 \mathrm{bl}$ in 1984 and the improvement rises to \$15.1bl by 1987. The GNP gains in the U.S. are eventually reversed. The dollar 
Table 9: Effects of U.S. Fariff Increase

\begin{tabular}{|c|c|c|c|c|c|}
\hline & & 1984 & 1985 & 1986 & 1987 \\
\hline \multicolumn{6}{|l|}{ U.S. Economy: } \\
\hline GNP $(\$ 84)$ & $\%$ & 0.2 & 0.2 & 0.1 & 0.0 \\
\hline $\operatorname{GNP}(\$ 84)$ & $\$ \mathrm{~b} 1$ & $7 \cdot 6$ & 5.8 & 2.2 & -1.6 \\
\hline Inflation & $\mathrm{D}$ & 0.0 & 0.1 & 0.1 & 0.1 \\
\hline Interest rate & D & 0.2 & 0.2 & 0.2 & 0.3 \\
\hline Exchange rate $(\mathrm{Ecu} / \$)$ & $\%$ & 3.4 & 3.4 & 3.4 & 3.4 \\
\hline Trade balance $(\$ 84)$ & $\$ \mathrm{~b} 1$ & $3 \cdot 8$ & $3 \cdot 1$ & 2.4 & 1.9 \\
\hline U.S. current a/c $(\$)$ & $\$ b l$ & $3 \cdot 3$ & 2.8 & $2 \cdot 1$ & 1.6 \\
\hline
\end{tabular}

Japanese Economy:

$\begin{array}{lccccc}\text { GNP } & \% & 0.3 & -0.5 & -1.1 & -1.3 \\ \text { Inflation } & \mathrm{D} & 0.9 & 1.0 & 0.7 & 0.4 \\ \text { Interest rate } & \mathrm{D} & 0.2 & 0.7 & 1.0 & 1.2 \\ \text { Exchange rate }(\mathrm{Yen} / \$) & \% & 12.4 & 12.7 & 13.3 & 14.0 \\ \text { Trade balance }(\$ 84) & \$ \mathrm{bl} & -5.8 & -7.0 & -7.1 & -6.4 \\ \text { Japan current a/c }(\$) & \$ \mathrm{~b} 1 & -5.5 & -7.0 & -7.6 & -7.4\end{array}$

OECD Economies:

$\begin{array}{llllll}\text { GNP } & \% & 0.2 & 0.1 & 0.0 & -0.1 \\ \text { Inflation } & \mathrm{D} & 0.0 & 0.1 & 0.1 & 0.0 \\ \text { Interest rate } & \mathrm{D} & 0.2 & 0.2 & 0.2 & 0.2 \\ \text { Trade balance }(\$ 84) & \$ \mathrm{bl} & 3.8 & 2.4 & 1.0 & 0.1 \\ \text { OECD current a/c }(\$) & \$ \mathrm{bl} & 4.0 & 3.0 & 2.0 & 1.4\end{array}$

Bilateral Trade (\% U.S. GNP) :

$\begin{array}{llrrrr}\text { U.S. net exports to Japan } & \% & 0.4 & 0.4 & 0.4 & 0.4 \\ & (\$ 84 \mathrm{~b} 1) & 14.0 & 14.7 & 15.0 & 15.1 \\ \text { U.S. net exports to OECD } & \% & -0.2 & -0.2 & -0.2 & -0.2 \\ & (\$ 84 \mathrm{~b} 1) & -7.9 & -8.2 & -8.5 & -8.8 \\ \text { Japan net exports to OECD } & \% & 0.1 & 0.1 & 0.1 & 0.1 \\ & (\$ 84 \mathrm{~b} 1) & 4.0 & 3.9 & 4.0 & 4.5\end{array}$


appreciates relative to both the Yen and Ecu as demand pressures push up interest rates in the U.S. This appreciation together with the increase in import demand implies that the U.S. overall trade balance improves only by $\$ 3.8$ bl in 1984 , with the gain from reduced Japanese imports being substantially offset by other bilateral deficits. The shift in U.S. demand is reflected in GNP gains both for the U.S. and ROECD. Note however that by 1987 rising interest rates and the strong dollar crowd out any further gains.l

Table 10 shows the case where Japan responds with a similar tariff increase (with revenues redistributed). The bilateral trade gains for the U.S. in relation to Japan are reduced from $\$ 14 \mathrm{bl}$ to $6.8 \mathrm{bl}$ in 1984 . The gains to U.S. GNP are also reduced and turn negative by 1986. The rise in U.S. goods prices in Japan induces Japanese residents to substitute away from the U.S. goods. This reduces the demand for dollars and hence reduces the depreciation of the Yen which occurs as a results of U.S. policy. The Japanese trade balance deterioration is reversed slightly to an overall decline of $\$ 4.0$ bl in 1984 .

D. Oil Price Shock

The effects of an oil price shock are shown in Table 1l. Inflation rises in each of the industrialized regions with Japan being hardest hit. The Dollar depreciates relative to the Ecu but appreciates relative to the Yen. The Yen depreciates relative to all currencies. The depreciated Yen contributes to the inflationary impulse in Japan, while the terms-of-trade loss causes an

lWe also considered the case where the revenue from the tariff is used to reduce the U.S. budget deficit. In this case U.S. GNP declines in the first year by $\$ 1.8 \mathrm{bl}$ and continues to fall as a result of the tariff. There is some offset to this decline from gradually falling interest rates but this is insufficient to counter the effect of the fall in demand. The U.S. trade 


\begin{tabular}{|c|c|c|c|c|c|}
\hline & & 1984 & 1985 & 1986 & 1987 \\
\hline \multicolumn{6}{|l|}{ U.S. Economy: } \\
\hline GNP $(\$ 84)$ & $\%$ & 0.2 & 0.0 & -0.2 & -0.4 \\
\hline GNP $(\$ 84)$ & $\$ b 1$ & 8.7 & 0.4 & -8.4 & $-15 \cdot 9$ \\
\hline Inflation & D & 0.2 & 0.3 & 0.3 & 0.2 \\
\hline Interest rate & $\mathrm{D}$ & 0.2 & 0.4 & 0.4 & 0.5 \\
\hline Exchange rate $(\operatorname{Ecu} / \$)$ & $\%$ & 1.8 & 1.8 & 1.7 & 1.6 \\
\hline Trade balance $(\$ 84)$ & $\$ \mathrm{bl}$ & 1.3 & 1.2 & 1.2 & 1.3 \\
\hline U.S. current a/c (\$) & $\$ \mathrm{bl}$ & 1.5 & 0.4 & 0.0 & -0.2 \\
\hline \multicolumn{6}{|l|}{ Japanese Economy: } \\
\hline GNP & $\%$ & 0.2 & -0.6 & $-1 \cdot 1$ & $-1 \cdot 3$ \\
\hline Inflation & $\mathrm{D}$ & 1.0 & 1.0 & 0.7 & 0.4 \\
\hline Interest rate & $\mathrm{D}$ & 0.2 & 0.7 & 1.0 & 1.2 \\
\hline Exchange rate $($ Yen $/ \$)$ & $\%$ & $5 \cdot 1$ & $5 \cdot 2$ & $5 \cdot 5$ & 6.0 \\
\hline Trade balance $(\$ 84)$ & $\$ \mathrm{~b} 1$ & $-4 \cdot 0$ & $-4 \cdot 9$ & -5.0 & $-4 \cdot 4$ \\
\hline Japan current a/c (\$) & $\$ \mathrm{bl}$ & $-3 \cdot 9$ & $-4 \cdot 8$ & $-5 \cdot 1$ & $-4 \cdot 9$ \\
\hline \multicolumn{6}{|l|}{ OECD Economies: } \\
\hline GNP & $\%$ & 0.2 & 0.1 & 0.0 & -0.1 \\
\hline Inflation & $\mathrm{D}$ & 0.0 & 0.1 & 0.1 & 0.1 \\
\hline Interest rate & $\mathrm{D}$ & 0.2 & 0.2 & 0.3 & $0 \cdot 3$ \\
\hline Trade balance $(\$ 84)$ & $\$ \mathrm{~b} 1$ & $3 \cdot 2$ & $3 \cdot 1$ & 2.6 & 1.8 \\
\hline OECD current a/c (\$) & $\$ b 1$ & $2 \cdot 9$ & $4 \cdot 5$ & $4 \cdot 5$ & 4.0 \\
\hline \multicolumn{6}{|l|}{ Bilateral Trade (\% U.S. GNP): } \\
\hline U.S. net exports to Japan & $\%$ & $\begin{array}{l}0.2 \\
6.8\end{array}$ & $\begin{array}{l}0.2 \\
7.4\end{array}$ & $\begin{array}{l}0.2 \\
7 \cdot 7\end{array}$ & $\begin{array}{l}0.2 \\
7.7\end{array}$ \\
\hline U.S. net exports to $O E C D$ & $\stackrel{\%}{(\$ 84 \mathrm{bl})}$ & $\begin{array}{l}-0.1 \\
-4.4\end{array}$ & $\begin{array}{l}-0.1 \\
-4 \cdot 7\end{array}$ & $\begin{array}{l}-0.1 \\
-4.8\end{array}$ & $\begin{array}{l}-0.1 \\
-4.6\end{array}$ \\
\hline Japan net exports to OECD & $\stackrel{\%}{(\$ 84 \mathrm{bl})}$ & $\begin{array}{l}0.0 \\
1.3\end{array}$ & $\begin{array}{l}0.0 \\
1.1\end{array}$ & $\begin{array}{l}0.0 \\
1.1\end{array}$ & $\begin{array}{l}0.0 \\
1.3\end{array}$ \\
\hline
\end{tabular}


Table 11: Effects of OPEC Price Shock

\begin{tabular}{|c|c|c|c|c|c|}
\hline & & 1984 & 1985 & 1986 & 1987 \\
\hline \multicolumn{6}{|l|}{ U.S. Economy: } \\
\hline $\begin{array}{ll}\text { GNP } & (\$ 84) \\
\text { GNP } & (\$ 84)\end{array}$ & $\begin{array}{l}\% \\
\$ \mathrm{bl}\end{array}$ & $\begin{array}{r}0.3 \\
11.6\end{array}$ & $\begin{array}{l}-0.2 \\
-7.0\end{array}$ & $\begin{array}{r}-0.7 \\
-25.7\end{array}$ & $\begin{array}{r}-1.2 \\
-46.6\end{array}$ \\
\hline Inflation & $\mathrm{D}$ & 0.8 & 1.0 & 0.9 & 0.7 \\
\hline Interest rate & $\mathrm{D}$ & 0.3 & 0.8 & 1.4 & 1.6 \\
\hline Exchange rate $($ Ecu $/ \$)$ & $\%$ & -0.1 & -0.1 & -0.2 & -0.2 \\
\hline Trade balance $(\$ 84)$ & $\$ \mathrm{bl}$ & $-5 \cdot 3$ & -1.6 & 3.2 & 6.2 \\
\hline U.S. current a/c $(\$)$ & $\$ \mathrm{bl}$ & $-3 \cdot 9$ & $-3 \cdot 6$ & -0.8 & 0.8 \\
\hline \multicolumn{6}{|l|}{ Japanese Economy: } \\
\hline GNP & $\%$ & 0.0 & -2.0 & $-3 \cdot 1$ & $-3 \cdot 7$ \\
\hline Inflation & $\mathrm{D}$ & 2.9 & 2.7 & $1 \cdot 9$ & $1 \cdot 1$ \\
\hline Interest rate & $\mathrm{D}$ & 0.0 & 1.5 & 2.6 & $3 \cdot 3$ \\
\hline Exchange rate $($ Yen $/ \$)$ & $\%$ & 2.0 & 1.7 & 2.1 & $2 \cdot 9$ \\
\hline Trade balance $(\$ 84)$ & $\$ \mathrm{bl}$ & $-13 \cdot 2$ & $-14 \cdot 1$ & $-11 \cdot 3$ & $-7 \cdot 8$ \\
\hline Japan current a/c (\$) & $\$ \mathrm{bl}$ & $-13 \cdot 1$ & $-13 \cdot 9$ & -11.8 & -8.8 \\
\hline \multicolumn{6}{|l|}{ OECD Economies: } \\
\hline GNP & $\%$ & 0.3 & -0.7 & -1.4 & $-1 \cdot 9$ \\
\hline Inflation & $\mathrm{D}$ & $1 \cdot 3$ & 1.4 & 1.1 & 0.7 \\
\hline Interest rate & $\mathrm{D}$ & 0.3 & 0.9 & 1.4 & 1.7 \\
\hline Trade balance $(\$ 84)$ & $\$ \mathrm{~b} 1$ & $-15 \cdot 9$ & $-11 \cdot 5$ & $-2 \cdot 0$ & 5.8 \\
\hline OECD current a/c $(\$)$ & $\$ \mathrm{bl}$ & $-17 \cdot 8$ & $-9 \cdot 6$ & 1.4 & 10.6 \\
\hline \multicolumn{6}{|l|}{ Bilateral Trade (\% U.S. GNP) : } \\
\hline U.S. net exports to Japan & $(\$ 84 \mathrm{bl})$ & $\begin{array}{r}0.0 \\
-1.2\end{array}$ & $\begin{array}{l}0.0 \\
0.0\end{array}$ & $\begin{array}{l}0.0 \\
0.4\end{array}$ & $\begin{array}{l}0.0 \\
0.2\end{array}$ \\
\hline U.S. net exports to OECD & $\begin{array}{l}\% \\
(\$ 84 \mathrm{bl})\end{array}$ & $\begin{array}{l}0.0 \\
0.4\end{array}$ & $\begin{array}{l}0.0 \\
1.0\end{array}$ & $\begin{array}{l}0.0 \\
1.4\end{array}$ & $\begin{array}{l}0.0 \\
1.5\end{array}$ \\
\hline Japan net exports to OECD & $\begin{array}{l}\% \\
(\$ 84 \mathrm{bl})\end{array}$ & $\begin{array}{l}0.0 \\
1.1\end{array}$ & $\begin{array}{l}0.0 \\
0.3\end{array}$ & $\begin{array}{l}0.0 \\
0.0\end{array}$ & $\begin{array}{l}0.0 \\
0.3\end{array}$ \\
\hline
\end{tabular}


increasing output decline, equal to $2 \%$ of GNP in 1985 and $3.7 \%$ in 1987 . The Japanese trade balance deteriorates due to the higher oil price.

E. Simulation results compared with other Models

We now briefly describe the multipliers for monetary and fiscal policy in the MCM (Federal Reserve Board Multicountry Model) and the EPA (Japanese Economic Planning Agency) models. These provide a useful benchmark for comparison with the policy multipliers from our own (IMS) model:

1. Fiscal Multipliers

The impact multipliers for GNP in the MCM and EPA models compared to our own "IMS" model are:

\begin{tabular}{lcccccc} 
& \multicolumn{2}{c}{ EPA } & \multicolumn{2}{c}{ MCM } & \multicolumn{2}{c}{ IMS } \\
& impact & 3 year & impact & 3 year & impact 3 year \\
U.S. & 2.0 & 1.93 & 1.5 & 0.83 & 1.0 & 1.0 \\
Japan & 1.1 & 1.5 & 1.2 & 1.4 & 0.6 & 0.7
\end{tabular}

The multipliers for GNP from these larger models are uniformly greater than we find. A major explanation of this difference is the importance of portfolio adjustment (including a high degree of sustitutability between U.S. and Japanese assets) and the greater flexibility of the exchange rate in our model. The trade

balance improves by $\$ 8.3$ bl and the bilateral U.S. Japan trade balance improves by $\$ 14.8 \mathrm{bl}$. Again there is a shift out of consumption of Japanese goods in the U.S. but the overall trade balance doesn't improve by as much because consumption of ROECD goods rises. 
balance in the expanding country deteriorates more in our model as the larger appreciation crowds out net exports, and this crowding out reduces the overall stimulus from the fiscal expansion. The large difference in exchange rate behavior is as follows. For the U.S. fiscal expansion we find a dollar appreciation of $4.0 \%$ and for the Japanese fiscal expansion we find a Yen appreciation of $3.2 \%$. In the EPA and MCM models, the dollar appreciation is much smaller at $.6 \%$ and $.3 \%$, respectively. In the EPA and MCM models, the Yen actually depreciates following a Japanese fiscal expansion by $1.5 \%$ and $.3 \%$.

\section{Monetary Multipliers}

A monetary expansion in the EPA model has a smaller impact on GNP than in our model. The multipliers are conveniently summarized as follows:

\begin{tabular}{cccccc} 
& \multicolumn{2}{c}{ EPA } & \multicolumn{2}{c}{ IMS } \\
& impact & 3 year & impact & 3 year \\
U.S. & 0.4 & 0.4 & & 0.9 & 0.6 \\
Japan & 0.04 & 0.09 & 0.8 & 0.5
\end{tabular}

The results from the monetary simulations differ far more from our model than do the fiscal policy simulations. (The MCM does not report a directly comparable experiment).

F. The Importance of the degree of $\$ /$ Yen Substitutability The move towards a more open financial system in Japan and the "Internationalization" of the Yen has important implications for monetary and fiscal policies. In this section we examine some of these implications. In the results above we have assumed a high degree of susbstitutability 
between Japanese and U.S. assets. Table 12 illustrates the consequences for fiscal policy if we reduce the degree of susbstitutability. The results reflect the effect of fiscal policy in a regime such as that in Japan before 1980 . In this case the yen exchange rate depreciates by $1.7 \%$ following a Japanese fiscal expansion. The output multipliers are also substantially larger with a rise in GNP of $1.7 \%$ on impact. These results are much closer to those discussed above for the MCM and EPA models.

If we take these results as the benchmark for pre-1980 and the results presented earlier as the situation with more flexible capital markets then the freeing up of capital flows has several important implications for Japan. A move to a more open financial system has the effect of lowering the effect of fiscal policy on GNP, but also reduces the inflationary consequences of a fiscal expansion. Higher substitutability also results in a positive transmission of the fiscal impulse to the U.S. and ROECD economies, while it means that a given fiscal stimulus causes a much larger deterioration in the trade balance and current account.

We can indirectly compare ours results with recent econometric estimates by Fukao(1985). He finds that a sterilized foreign exchange intervention by the Bank of Japan of $\$ 18$ billion to support the Yen would cause the Yen to appreciate by $3.8 \%$. In our case of low asset substitutability we find a Yen appreciation of $3.4 \%$ for the same amount of intervention. In contrast we find only a .5\% appreciation in our case of high asset substitutability, implying near perfect substitutability. There are two main reasons to believe that the econometric estimates are too low and that our assumptions may be more appropriate. First there has been continuing liberalization of the Yen in the last five 
Table 12: Effects of Japanese Fiscal Expansion

(Low asset substitutability)

\begin{tabular}{lllll}
\hline & 1984 & 1985 & 1986 & 1987 \\
\hline
\end{tabular}

U.S. Economy :

$\begin{array}{ll}\text { GNP } & (\$ 84) \\ \text { GNP } & (\$ 84)\end{array}$

Inflation

Interest rate

Exchange rate $(\mathrm{Ecu} / \$)$

Trade balance $(\$ 84)$

U.S. current $a / c(\$)$

Japanese Economy:

GNP

Inflation

Interest rate

Exchange rate $($ Yen $/ \$)$

Trade balance $(\$ 84)$

Japan current a/c (\$)

OECD Economies:

GNP

Inflation

Interest rate

Trade balance ( $\$ 84)$

OECD current a/c (\$)

Bilateral Trade (\% U.S. GNP):

U.S. net exports to Japan

U.S. net exports to OECD

Japan net exports to OECD

$\begin{array}{lrrrr}\% & 0.0 & -0.1 & 0.0 & 0.0 \\ \$ \mathrm{~b} 1 & -1.3 & -3.4 & -1.8 & 1.1 \\ D & 0.0 & -0.1 & -0.1 & -0.1 \\ D & 0.0 & -0.1 & -0.2 & -0.2 \\ \% & -0.1 & -0.1 & 0.0 & 0.0 \\ \$ \mathrm{~b} 1 & -0.3 & -1.4 & -1.7 & -1.9 \\ \$ \mathrm{~b} 1 & -0.2 & -1.0 & -0.9 & -0.6\end{array}$

$\%$

1.7

1.9

1.5

0.9

D

0.2

1.0

1.4

1.6

D

1.5

2.7

$3 \cdot 9$

5.2

$\%$

1.7

4.1

5.6

6.9

$\$ b 1$

0.6

3.0

3.7

4.1

$\$ b 1$

0.5

2.7

3.2

3.4

$\%$

0.0

$-0.1$

0.0

0.0

D

0.0

$-0.1$

$-0.1$

$-0.1$

D

0.0

$-0.1$

$-0.2$

$-0.2$

$\$ b 1$

$-0$

$-1.5$

$-1.8$

$-1.9$

$\$ b 1$

$-0.4$

$-1 \cdot 7$

$-2.5$

$-2.9$

$\begin{array}{lrrrr}\% & 0.0 & 0.0 & 0.0 & 0.0 \\ (\$ 84 \mathrm{bl}) & -0.6 & -1.5 & -1.8 & -1.8 \\ \% & 0.0 & 0.0 & 0.0 & 0.0 \\ (\$ 84 \mathrm{bl}) & 0.2 & 0.2 & 0.2 & 0.1 \\ \% & & & & \\ (\$ 84 \mathrm{bl} 1) & 0.0 & 0.0 & 0.0 & 0.0 \\ & 0.5 & 1.3 & 1.5 & 1.5\end{array}$


years, so that econometric estimates of the average substitutability during the period 1979 to 1983 (as by Fukao) will tend to underestimate the substitutability as of 1985. Second, movements in the Yen and dollar since 1980 are much easier to explain under the assumption of very high substitutability. We simulated a U.S. fiscal expansion of $1 \%$ of GNP in the case that we call low asset substitutability. In this case the Yen/\$ exchange rate only appreciates by 1.1\%. Together with the results presented in table 12 this implies that a shift in fiscal stance by the U.S. equal to a $4 \%$ of GNP fiscal expansion, and by Japan of $2 \%$ of GNP fiscal contraction (the approximate magnitudes since 1983), have the following effects in 1984 ( $\$$ billion):

$$
\text { U.S. Japan }
$$

Current Account $-65.6+2.2$

Bilateral Trade Balance $-4.4+4.4$

Yen $/ \$$ ( $\%$ change $)$

$1.0-1.0$

This compares with our results from assuming high asset substitutability:

Current Account

Bilateral Trade Balance

Yen $/ \$$ ( $\%$ change $)$

$$
\text { U.S. Japan }
$$$$
-77.8+28.8
$$$$
-16.0+16.0
$$

$20.8-20.8$ 
IV. ALTERINATVE SCENARIOS FOR THE NEXT FIVE YEARS

In this section we use the model to generate alternative paths for major variable in the three industrialized regions as a results of different assumption about monetary and fiscal policy. We examine four cases:

- A path of continued large U.S. fiscal deficits with small fiscal deficits in Japan and surpluses in ROECD;

- A gradual shift in U.S. policy towards smaller fiscal deficits and less tight monetary policy, with no change in Japanese or ROECD policies;

- The same U.S. policy path but with Japan responding to offset any harmful effects on GNP;

- The same U.S. policy path and Japanese response with the ROECD responding to offset the decline in GNP.

Case 1. Baseline with no policy change

In this section we use the model to generate a baseline simulation for the period from 1984 to 1989. Initial conditions are supplied to the model for GNP gap in the U.S., Japan, and the ROECD as well as initial inflation and initial real exchange rates and paths for fiscal policy and monetary policy. We assume that the money supply is adjusted to maintain a given path for real interest rates. Our other assumptions are the following: 


$\begin{array}{llc} & & 1984 \\ \text { GNP GAP } & \text { U.S. } & 3.4 \\ \text { (percent) } & \text { Japan } & 3.4 \\ & \text { ROECD } & 6.8 \\ & & \\ \text { Inflation } & \text { U.S. } & 3.8 \\ \text { (percent) } & \text { Japan } & 2.3 \\ & \text { ROECD } & 7.0\end{array}$

Policy:

$\underline{1984} \quad \underline{1985} \quad \underline{1986} \quad \underline{1987} \quad \underline{\underline{1988}} \quad \underline{1989}$

U.S.

Fiscal Deficit (\% GNP)

$3.7 \quad 3.9$

3.9

3.9

3.9

3.9

Real Interest Rate

$4.7 \quad 5.7$

6.7

$7 \cdot 7$

$7 \cdot 7$

$7 \cdot 7$

\section{Japan}

Fiscal Deficit (\% GNP)

Real Interest Rate

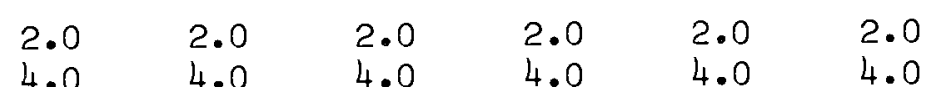

ROECD

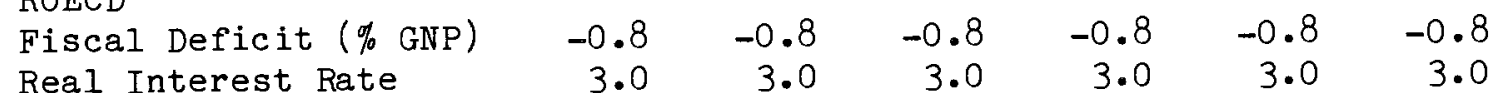

We make constant term adjustments to the model to improve the 1984 forecasts. The results from 1984 to 1989 are generated by the model dynamics. Table 13 contains the results for major variables in the three industrialized regions. Note that exchange rates are measured as percentage deviations from 1980 levels. The sustained fiscal deficits in the U.S. imply a rising path of real interest rates, and hence the output gap increases from $3.4 \%$ in 1984 to $5.0 \%$ in 1987 . This is accompanied by rising inflation to 1985 and a weakening dollar with inflation rising from $3.8 \%$ in 1984 to $4.5 \%$ in 1985 , then declining to $1.6 \%$ by 1989. There is little improvement in the bilateral U.S./Japan trade position. 
Table 13: Baseline Simulation

\begin{tabular}{|c|c|c|c|c|c|c|c|}
\hline & & 1984 & 1985 & 1986 & 1987 & 1988 & 1989 \\
\hline \multicolumn{8}{|l|}{ U.S. Economy: } \\
\hline GNP gap & $\%$ & -3.4 & $-4 \cdot 1$ & -4.8 & $-5 \cdot 0$ & $-4 \cdot 0$ & $-1 \cdot 3$ \\
\hline GNP gap & $\$ 84 \mathrm{bl}$ & $-123 \cdot 3$ & $-151 \cdot 5$ & $-182 \cdot 9$ & $-199 \cdot 6$ & $-161 \cdot 5$ & $-120 \cdot 5$ \\
\hline Inflation & & 3.8 & $4 \cdot 5$ & 3.7 & 2.8 & 1.9 & 1.6 \\
\hline Interest rate & & $9 \cdot 1$ & $9 \cdot 2$ & $9 \cdot 3$ & 9.4 & $9 \cdot 1$ & 8.9 \\
\hline Exchange rate $(\operatorname{Ecu} / \$)$ & $\%$ & $39 \cdot 0$ & $40 \cdot 5$ & 40.6 & $39 \cdot 2$ & 36.4 & 32.4 \\
\hline Trade balance & $\$ 84 \mathrm{bl}$ & -110.0 & -110.4 & $-103 \cdot 5$ & -91.4 & $-78 \cdot 2$ & $-65 \cdot 1$ \\
\hline U.S. current a/c & $\$ 84$ bl & $-98 \cdot 3$ & $-105 \cdot 2$ & $-106 \cdot 5$ & $-102 \cdot 5$ & -93.4 & $-85 \cdot 2$ \\
\hline \multicolumn{8}{|l|}{ Japanese Economy: } \\
\hline GNP gap & $\%$ & $-3 \cdot 4$ & $-3 \cdot 0$ & $-2 \cdot 2$ & $-1 \cdot 1$ & -0.2 & 1.7 \\
\hline Inflation & & $2 \cdot 3$ & 3.8 & $3 \cdot 3$ & $3 \cdot 1$ & $3 \cdot 2$ & 3.7 \\
\hline Interest rate & & 7.8 & $7 \cdot 2$ & $7 \cdot 0$ & $7 \cdot 1$ & $7 \cdot 5$ & $8 \cdot 3$ \\
\hline Exchange rate $($ Yen $/ \$)$ & $\%$ & 16.0 & $15 \cdot 0$ & $13 \cdot 9$ & $13 \cdot 1$ & $12 \cdot 9$ & 14.0 \\
\hline Trade balance & $\$ 84 \mathrm{bl}$ & $37 \cdot 9$ & 36.1 & 36.8 & 39.5 & $44 \cdot 1$ & 50.0 \\
\hline Japan current a/c & $\$ 84 \mathrm{bl}$ & $45 \cdot 7$ & $45 \cdot 7$ & 48.8 & 54.1 & 60.7 & 69.4 \\
\hline \multicolumn{8}{|l|}{ OECD Economies: } \\
\hline GNP gap & $\%$ & -6.8 & $-7 \cdot 3$ & $-7 \cdot 6$ & $-7 \cdot 7$ & $-7 \cdot 6$ & $-7 \cdot 5$ \\
\hline Inflation & & $7 \cdot 0$ & $7 \cdot 3$ & 5.6 & $3 \cdot 9$ & $2 \cdot 3$ & 0.7 \\
\hline Interest rate & & 10.4 & $8 \cdot 7$ & $7 \cdot 0$ & $5 \cdot 4$ & 3.8 & $2 \cdot 2$ \\
\hline Trade balance $(\$ 84)$ & $\$ 84 \mathrm{bl}$ & $35 \cdot 9$ & $27 \cdot 1$ & $22 \cdot 6$ & 20.8 & 21.0 & $22 \cdot 1$ \\
\hline OECD current a/c $(\$)$ & $\$ 84$ bl & $34 \cdot 5$ & $25 \cdot 3$ & $22 \cdot 5$ & $22 \cdot 3$ & $21 \cdot 7$ & $24 \cdot 1$ \\
\hline \multicolumn{8}{|l|}{ Bilateral Trade (\% U.S. GNP): } \\
\hline U.S. net exports to Japan & $\begin{array}{l}\% \\
\$ 84 \text { b1 }\end{array}$ & $\begin{array}{r}-1 \cdot 1 \\
-38 \cdot 5\end{array}$ & $\begin{array}{r}-1.0 \\
-38.8\end{array}$ & $\begin{array}{r}-1.0 \\
-38.8\end{array}$ & $\begin{array}{r}-1.0 \\
-38 \cdot 5\end{array}$ & $\begin{array}{r}-0.9 \\
-38.5\end{array}$ & $\begin{array}{r}-0.9 \\
-39.0\end{array}$ \\
\hline U.S. net exports to OECD & $\begin{array}{l}\% \\
\$ 84 \mathrm{bl}\end{array}$ & $\begin{array}{r}-1.1 \\
-38.2\end{array}$ & $\begin{array}{r}-1.0 \\
-35.5\end{array}$ & $\begin{array}{r}-0.8 \\
-30.4\end{array}$ & $\begin{array}{r}-0.6 \\
-23 \cdot 3\end{array}$ & $\begin{array}{r}-0.4 \\
-15.5\end{array}$ & $\begin{array}{l}-0.2 \\
-7.9\end{array}$ \\
\hline Japan net exports to OECD & $\begin{array}{l}\% \\
\$ 84 \mathrm{bl}\end{array}$ & $\begin{array}{r}0.3 \\
11.7\end{array}$ & $\begin{array}{r}0.3 \\
12.5\end{array}$ & $\begin{array}{r}0.4 \\
13.6\end{array}$ & $\begin{array}{r}0.4 \\
15.1\end{array}$ & $\begin{array}{r}0.4 \\
16.9\end{array}$ & $\begin{array}{r}0.5 \\
19.1\end{array}$ \\
\hline
\end{tabular}


Case 2. Gradual Shift in U.S. policy mix

Table 14 contains the results for a change in U.S. fiscal policy towards smaller fiscal deficits and less tight monetary policy. The results are presented as deviations from the baseline. The policy followed is a reduction in the fiscal deficit (as a percent of GNP) and a rise in the level of nominal money balances of the following:

\begin{tabular}{|c|c|c|c|c|c|c|}
\hline & 1984 & 1985 & 1986 & 1987 & 1988 & 1989 \\
\hline Fiscal Deficit & $-0.5 \%$ & $-1.0 \%$ & $-1.5 \%$ & $-2.0 \%$ & $-2.5 \%$ & $-3 \cdot 0$ \\
\hline Money Supply & 0 & $0.8 \%$ & $1.6 \%$ & $3.0 \%$ & $5.0 \%$ & 7.0 \\
\hline
\end{tabular}

with the deficit at $3.0 \%$ of GNP below the baseline from 1990 onwards and money growing at $2 \%$ above base from 1989 onwards. This monetary policy is chosen so as to prevent output from falling in the initial stages of the policy shift. Notice that output in the U.S. rises in 1984 despite the fiscal contraction and no change in level of nominal money balances that year. This arises partly from the forward-looking behavior in the asset markets in our model. The expected future fiscal contraction/monetary expansion and hence expected depreciation of the exchange rate induces a large current depreciation which stimulates demand for U.S. goods in 1984. The trade balance improves by $\$ 24$ bl which accounts for most of the rise in GNP. The dollar continues to depreciate relative to both the Yen and the Ecu as U.S. interest rates fall. Inflation rises by $0.5 \%$ in 1984 due to the depreciation and rises further in 1985 as demand pressure feeds through to prices.

Japan and the ROECD are both adversely affected by the change in U.S. 
Table 14: Effects of Gradual Change U.S. Fiscal/Monetary Mix (Deviations from Baseline in Table 13)

1984

1985

1986

1987

U.S. Economy:

GNP (\$84)

GNP $(\$ 84)$

Inflation

Interest rate

Exchange rate $(\mathrm{Ecu} / \$)$

Trade balance ( $\$ 84)$

U.S. current a/c (\$)

Japanese Economy:

GNP

Inflation

Interest rate

Exchange rate (Yen $/ \$$ )

Trade balance $(\$ 84)$

Japan current a/c (\$)

OECD Economies:

GNP

Inflation

Interest rate

Trade balance $(\$ 84)$

OECD current a/c (\$)

Bilateral Trade (\% U.S. GNP) :

U.S. net exports to Japan

U.S. net exports to OECD

Japan net exports to OECD

$\begin{array}{lrrrr}\text { \% } & 0.7 & 0.1 & -0.5 & -0.6 \\ \text { \$b1 } & 26.3 & 4.8 & -19.4 & -24.5 \\ \text { D } & 0.5 & 0.8 & 0.8 & 0.6 \\ \text { D } & 0.6 & 0.1 & -0.5 & -1.6 \\ \% & -7.7 & -9.6 & -11.5 & -13.6 \\ \text { \$b1 } & 23.8 & 28.8 & 34.4 & 39.0 \\ \text { \$b1 } & 24.2 & 30.3 & 39.0 & 49.4\end{array}$

$\%$

D

D

$\%$

$\$ \mathrm{~b} 1$

\$bl

$$
-0.9
$$$$
-0.7
$$$$
-0.5
$$$$
-0 \cdot 3
$$

$-0.2$

$-0.6$

$-0.7$

$-0.0$

D

$-0.8$

$-1.4$

$-1.9$

$-2.6$

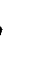

$-7 \cdot 0$

$-8.6$

$-10 \cdot 3$

$-12.1$

$-4.7$

$-4 \cdot 9$

$-5 \cdot 2$

$-5.9$

$-4.8$

$-4.9$

$-5.8$

$-7 \cdot 7$

$\%$

$$
-1.2
$$

$-0$.

$-0.5$

0.0

D

$-0.3$

$-0.8$

$-0.9$

$-0.9$

D

$-1.1$

$-1 \cdot 7$

$-2 \cdot 3$

$-2.9$

\$bl

$-21.3$

$-23.4$

$-26.6$

$-31.2$

\$bl

$-21.5$

$-23.5$

$-29.6$

$-39 \cdot 3$

$\begin{array}{lrrrr}\% & 0.1 & 0.1 & 0.1 & 0.2 \\ (\$ 84 \mathrm{bl} 1) & 4.3 & 4.9 & 5.7 & 6.4 \\ \% & 0.5 & 0.5 & 0.6 & 0.6 \\ (\$ 84 \mathrm{bl} 1) & 16.9 & 19.4 & 22.4 & 25.4 \\ \% & & & & \\ (\$ 84 \mathrm{bl}) & 0.0 & 0.0 & 0.0 & 0.1 \\ & 1.3 & 1.4 & 1.7 & 2.1\end{array}$


policy. The weakening of the dollar worsens the trade position of both regions and, without any policy actions, the GNP gap increases in both these regions. The Yen depreciates relative to the Ecu due to the differential impact of the U.S. policy shift on trade between the regions. The impact of both the appreciation and the decline in demand for Japanese goods is reflected in the fall in inflation of $.2 \%$ in 1984 , and a continuing fall in inflation thereafter. Case 3. Japanese response to the shift in U.S. policy

In Table 15 we illustrate the effects of a policy response in Japan to the change in U.S. policy. We assume that Japan follows a more expansionary fiscal policy, increasing bond-financed government spending by $1 \%$ of GNP. We also assume a Japanese monetary expansion of $0.5 \%$ in the level of nominal money balances. This policy response keeps Japanese GNP approximately unchanged from the initial baseline. This response strengthens the Yen further relative to both the dollar and the Ecu. Inflation remains lower in Japan despite the fiscal and monetary expansion since the strong Yen offsets the effect of rising domestic prices on the CPI. The switch in U.S. policy has a favorable impact on Japanese output and inflation when accompanied by expansionary policies in Japan. Note that in the planning model used by the Ministry of Finance, the inflationary consequences of a fiscal expansion would be larger than are reported here. This is in part because the MOF model would predict a smaller exchange rate appreciation. Case 4. ROECD response to the shift in U.S. and Japanese policy

Table 16 contains the results for a change in ROECD policy given the switch in the U.S. fiscal/monetary mix and the Japanese policy response. We assume 
Table 15: Effects of Gradual Change in U.S. Fiscal/Monetary Mix with Japanese Policy Response

\begin{tabular}{|c|c|c|c|c|c|}
\hline & & 1984 & 1985 & 1986 & 1987 \\
\hline U.S. Economy: & & \multicolumn{4}{|c|}{ (Woviation Prom zareinas) } \\
\hline $\begin{array}{ll}\text { GNP } & (\$ 84) \\
\text { GNP } & (\$ 84)\end{array}$ & $\begin{array}{l}\% \\
\$ \mathrm{bl}\end{array}$ & $\begin{array}{r}0.9 \\
33.2\end{array}$ & $\begin{array}{l}0.3 \\
9 \cdot 5\end{array}$ & $\begin{array}{r}-0 \cdot 5 \\
-17 \cdot 3\end{array}$ & $\begin{array}{r}-0.6 \\
-25.6\end{array}$ \\
\hline Inflation & $\mathrm{D}$ & 0.6 & 1.0 & 0.9 & 0.7 \\
\hline Interest rate & $\mathrm{D}$ & 0.8 & 0.4 & -0.2 & $-1 \cdot 1$ \\
\hline Exchange rate $(\mathrm{Ecu} / \$)$ & $\%$ & -7.8 & $-9 \cdot 6$ & -11.6 & $-13 \cdot 6$ \\
\hline Trade balance $(\$ 84)$ & $\$ \mathrm{bl}$ & $26 \cdot 3$ & 31.6 & $37 \cdot 7$ & $42 \cdot 7$ \\
\hline U.S. current a/c (\$) & $\$ b 1$ & 26.7 & $32 \cdot 7$ & 41.5 & 52.2 \\
\hline
\end{tabular}

Japanese Economy:

$\begin{array}{llllll}\text { GNP } & \% & 0.0 & 0.3 & 0.4 & 0.4 \\ \text { Inflation } & \mathrm{D} & -0.5 & -0.4 & -0.4 & -0.3 \\ \text { Interest rate } & \mathrm{D} & -0.6 & -0.8 & -1.1 & -1.3 \\ \text { Exchange rate (Yen/\$) } & \% & -9.6 & -11.1 & -12.8 & -14.5 \\ \text { Trade balance }(\$ 84) & \$ \mathrm{bl} & -10.1 & -10.3 & -11.1 & -12.2 \\ \text { Japan current a/c (\$) } & \$ \mathrm{bl} & -10.3 & -10.4 & -12.0 & -14.7 \\ \text { CD Economies: } & & & & & \\ \text { GNP } & \% & -1.1 & -0.8 & -0.4 & 0.0 \\ \text { Inflation } & \mathrm{D} & -0.2 & -0.7 & -0.8 & -0.8 \\ \text { Interest rate } & \mathrm{D} & -1.0 & -1.5 & -2.0 & -2.5 \\ \text { Trade balance }(\$ 84) & \$ b l & -18.8 & -20.3 & -22.7 & -26.8 \\ \text { OECD current a/c }(\$) & \$ b l & -19.0 & -19.4 & -24.3 & -32.9\end{array}$

Bilateral Trade (\% U.S. GNP):

U.S. net exports to Japan 
Table 16: Effects of Gradual Change in U.S. Fiscal/Monetary Mix with Both Japan and ROECD Reacting

\begin{tabular}{|c|c|c|c|c|c|}
\hline & & 1984 & 1985 & 1986 & 1987 \\
\hline U.S. Economy: & & \multicolumn{4}{|c|}{ (Weviation from Laseline) } \\
\hline $\begin{array}{ll}\text { GNP } & (\$ 84) \\
\text { GNP } & (\$ 84)\end{array}$ & $\begin{array}{l}\% \\
\$ \mathrm{bl} 1\end{array}$ & $\begin{array}{r}1.4 \\
50.6\end{array}$ & $\begin{array}{r}0.5 \\
18.5\end{array}$ & $\begin{array}{l}-0.4 \\
-14.6^{-4}\end{array}$ & $\begin{array}{r}-0.8 \\
-30.3\end{array}$ \\
\hline Inflation & $\mathrm{D}$ & 0.7 & 1.2 & 1.2 & 1.0 \\
\hline Interest rate & $\mathrm{D}$ & 1.2 & 0.9 & 0.6 & $-0 \cdot 3$ \\
\hline Exchange rate $($ Ecu $/ \$)$ & $\%$ & -9.8 & $-11 \cdot 2$ & $-13 \cdot 1$ & $-15 \cdot 1$ \\
\hline Trade balance $(\$ 84)$ & $\$ b 1$ & 33.2 & $37 \cdot 5$ & 44.0 & 49.4 \\
\hline U.S. current a/c (\$) & $\$ b l$ & $33 \cdot 3$ & $37 \cdot 5$ & 46.6 & $57 \cdot 2$ \\
\hline \multicolumn{6}{|l|}{ Japanese Economy: } \\
\hline GNP & $\%$ & 0.3 & 0.4 & 0.5 & 0.4 \\
\hline Inflation & $\mathrm{D}$ & -0.3 & -0.2 & -0.2 & -0.1 \\
\hline Interest rate & $\mathrm{D}$ & -0.3 & -0.4 & -0.5 & -0.7 \\
\hline Exchange rate $($ Yen $/ \$)$ & $\%$ & -9.8 & $-11 \cdot 5$ & $-13 \cdot 3$ & $-15 \cdot 1$ \\
\hline Trade balance $(\$ 84)$ & $\$ b l$ & -7.9 & $-8 \cdot 7$ & -9.4 & -10.7 \\
\hline Japan current a/c (\$) & $\$ b 1$ & $-8 \cdot 0$ & $-8 \cdot 2$ & $-9 \cdot 5$ & $-12 \cdot 2$ \\
\hline \multicolumn{6}{|l|}{ OECD Economies: } \\
\hline GNP & $\%$ & 0.0 & $-0 \cdot 3$ & 0.0 & 0.1 \\
\hline Inflation & $\mathrm{D}$ & $-0 \cdot 3$ & $-0 \cdot 3$ & -0.4 & -0.4 \\
\hline Interest rate & $\mathrm{D}$ & 0.0 & -0.6 & -0.9 & -1.2 \\
\hline Trade balance $(\$ 84)$ & $\$ b l$ & $-28 \cdot 6$ & $-26 \cdot 7$ & $-28 \cdot 5$ & -32.7 \\
\hline OECD current a/c $(\$)$ & $\$ b l$ & $-28 \cdot 2$ & $-24 \cdot 3$ & $-28 \cdot 3$ & $-36 \cdot 7$ \\
\hline \multicolumn{6}{|l|}{ Bilateral Trade ( $\%$ U.S. GNP): } \\
\hline U.S. net exports to Japan & $\begin{array}{l}\% \\
(\$ 84 b 1)\end{array}$ & $\begin{array}{l}0.2 \\
6.2\end{array}$ & $\begin{array}{l}0.2 \\
7.1\end{array}$ & $\begin{array}{l}0.2 \\
8.2\end{array}$ & $\begin{array}{l}0.2 \\
9.2\end{array}$ \\
\hline U.S. net exports to OECD & $\begin{array}{l}\% \\
(\$ 84 b 1)\end{array}$ & $\begin{array}{r}0.6 \\
22.9\end{array}$ & $\begin{array}{r}0.6 \\
24.0\end{array}$ & $\begin{array}{r}0.7 \\
27.1\end{array}$ & $\begin{array}{r}0.8 \\
30.4\end{array}$ \\
\hline Japan net exports to OECD & $\begin{array}{l}\% \\
(\$ 84 b 1)\end{array}$ & $\begin{array}{l}0.0 \\
1.4\end{array}$ & $\begin{array}{l}0.0 \\
1.0\end{array}$ & $\begin{array}{l}0.0 \\
1.1\end{array}$ & $\begin{array}{l}0.0 \\
1.2\end{array}$ \\
\hline
\end{tabular}


that the ROECD adjusts fiscal policy such that the GNP gap returns to its value before the U.S. policy shift. In this case we assume an increase in the ROECD fiscal deficit of $.75 \%$ of ROECD GNP in 1984 and $.4 \%$ thereafter. The ROECD fiscal expansion returns the ROECD output gap to its original level. It also proves to be beneficial (in terms of higher GNP) to both the U.S. and Japan as both these regions trade positions improve. As a result of the U.S. policy shift with compensating changes in Japan and the ROECD the dollar is depreciated by $9.8 \%$ in 1984 and $15.1 \%$ by 1987 relative to both Yen and Ecu. Inflation is reduced in ROECD and Japan although inflation rises in the U.S. as it reimports some of the inflation that it exported in the years prior to 1984 when it maintained a strong dollar. Interest rates are also reduced in ROECD and Japan with initially higher interest rates in the U.S. The trade imbalances of 1984 are reduced by the policy; the U.S. trade balance is improved by $\$ 33$ bl in 1984 and the Japanese and ROECD surpluses are reduced. The bilateral deficit that the U.S. has with the ROECD is reduced by $\$ 22.9$ bl in 1984 although the U.S.-Japan trade imbalance only falls by $\$ 6.2$ bl in 1984 .

V. POLICY COORDINATION AND OPTIMAL POLICY RESPONSE TO THE CURRENT BASELINE In this section we use dynamic programming techniques to find the optimal dynamic policy path for each country, assuming that policy-makers are acting to stabilize four targets: output, inflation, the current account, and the fiscal deficit. We compare the path of the world economy that is reached when policy-makers in each country optimize in a coordinated fashion, with the path which emerges from no change in current policies (i.e., our baseline path). 
The techniques used in this section are more formally developed in Oudiz and Sachs (1984) and Sachs and McKibbin (1985).

We assume that each region $i(i=U . S$, Japan, ROECD) has a welfare function of the form $V_{i}=-\frac{1}{2} \sum_{t=0}^{\infty} \beta^{t} V\left(Q_{t i}, \pi_{t i}^{c}, C_{t i}, D E F F_{t i}\right)$

where $Q_{t i}$ is the output gap

$\pi_{t i}^{c}$ is the rate of CPI inflation

$\mathrm{CA}_{i}$ is the current account

$D E_{i}$ is the fiscal deficit

We select a quadratic form for $V$. Specifically, we assume $\beta=(1 / 1.1)$ and

$$
\begin{aligned}
& v_{i}=a_{1 i} Q_{t i}^{2}+a_{2 i}\left({ }_{t i}^{c}\right)^{2}+a_{3 i}\left(C A_{t i}\right)^{2}+a_{4 i} D E F_{t i}^{2} \text {. } \\
& \text { Where } i=\text { U.S. Japan ROECD } \\
& \begin{array}{llll}
\mathrm{a}_{1} & 1.0 & 1.0 & 1.7 \\
\mathrm{a}_{2} & 0.8 & 0.8 & 0.8 \\
\mathrm{a}_{3} & 0.8 & 0.8 & 1.7 \\
\mathrm{a}_{4} & 0.05 & 0.08 & 0.05
\end{array}
\end{aligned}
$$

In the decentralized case (also known as the non-cooperative equilibrium or Nash equilibrium) we assume that each region selects policies ( $M, G$, and $T$ ) to maximize the welfare function $\mathrm{V}_{i}$, given the structure of our model and taking the actions of other governments as given. This involves complex dynamic programming techniques and will not be discussed any further here (see Oudiz and Sachs $(1984))$.

In this paper we are primarily concerned with the implications of policy coordination, so we only report the outcome of policy coordination between the three industrialized regions in response to the conditions assumed in the baseline. We model the coordination by assuming a central policy authority carrying out the optimization problem outlined above. In this case the weights on each 
country in the coalition are chosen so that each country in the coalition is at least as well of under coordination as it is under the non-cooperative regime (not reported). The weights are the following: U.S. (.34), Japan (.21), ROECD (.45). The policies followed are (as deviation from the baseline policies):

$$
\underline{1984} \quad \underline{1985} \quad \underline{1986} \quad \underline{1987} \quad \underline{1988} \quad \underline{1989}
$$

U.S.:

\section{Fiscal Policy}

Deficit ( $\%$ GNP)

Monetary Policy

Money ( $\%$ deviation

from base)

Japan:

Fiscal Policy

Deficit (\% GNP)

Monetary Policy

Money ( $\%$ deviation

from base)

ROECD :

Fiscal Policy

Deficit (\% GNP)

Monetary Policy

Money (\% deviation

from base)

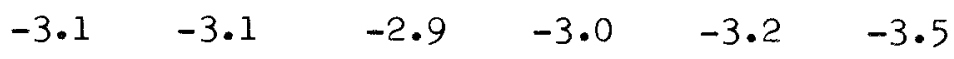

$\begin{array}{llllll}1.2 & 3.0 & 4.6 & 6.2 & 6.8 & 7.5\end{array}$

$\begin{array}{llllll}1.4 & 2.0 & 1.7 & 1.4 & 1.1 & 0.8\end{array}$

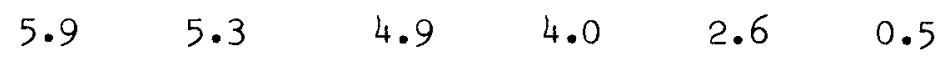

$\begin{array}{llllll}0.5 & 1.1 & 1.2 & 1.3 & 1.4 & 1.4\end{array}$

It is clear from this table that given our assumed utility functions there is a generalized expansion in the world money supply. The U.S. has a fiscal contraction whereas Japan and the ROECD have fiscal expansions relative to base. Note that although the Japanese fiscal expansion is initially greater than the ROECD fiscal expansion, the Japanese fiscal expansion declines over time whereas 
the ROECD fiscal expansion continues to increase. The consequences of these policies are shown in table 17. The output gap initially rises in the U.S. due to the contraction in fiscal policy, though it falls relative to base from 1986 onwards. The monetary expansion in the U.S. together with the relatively depreciated exchange rate has an inflationary consequence in the U.S. with inflation $0.8 \%$ higher than base in 1984. The depreciated dollar means that Japan and ROECD escape the inflationary consequences of their respective monetary expansions although the ROECD quickly loses its deflationary gains as the monetary expansion outweighs the effect of the currency appreciation on domestic prices. By 1986 inflation is $1.6 \%$ higher than base in the ROECD but this is accompanied by a reduction in the output gap of $4.3 \%$. The output gap in both Japan and ROECD declines due to the monetary and fiscal expansions. The U.S. trade deficit is reduced by $\$ 52$ bl in 1984 , at the expense of the ROECD trade surplus, which falls by $\$ 48$ bl in 1984. This shift is the result of several factors. From the policy multipliers presented above we know that a U.S. fiscal contraction of $3.1 \%$ improves the U.S. trade balance by $\$ 48$ bl, and worsens the ROECD trade account by $\$ 44$ bl. An ROECD fiscal expansion of $0.5 \%$ adds a further $\$ 6$ bl improvement to the U.S. trade account, and a further $\$ 8$ bl worsening of the ROECD trade account. The Japanese fiscal expansion of $1.4 \%$ also improves the U.S. and ROECD trade balances by $\$ 4$ bl each. Given the fact that monetary expansion in our model causes the expanding country's output to rise, with little effect on the trade balance or on the output of other countries, our model concludes that fiscal policy redistributes bilateral trade imbalances while monetary policy expands domestic demand with 
Table 17: Outcome of Optimal Cooperative Response to Baseline

\begin{tabular}{|c|c|c|c|c|c|c|c|}
\hline & & 1984 & $19 \overline{85}$ & 1986 & 1987 & 1988 & 19 \\
\hline U.S. Economy: & & & & & & & \\
\hline GNP gap & $\%$ & $-5 \cdot 4$ & -4.8 & -4.2 & -3.8 & $-3 \cdot 3$ & \\
\hline GNP gap & $\$ 84 \mathrm{~b} 1$ & -195.0 & $-178 \cdot 3$ & -163.2 & $-149 \cdot 3$ & $-136 \cdot 3$ & -123 \\
\hline Inflation & & 4.6 & 4.6 & 3.9 & $3 \cdot 3$ & 2.8 & \\
\hline Interest rate & & 6.0 & 5.2 & 4.9 & $4 \cdot 5$ & $3 \cdot 9$ & \\
\hline Exchange rate $(\mathrm{Ecu} / \$)$ & $\%$ & $28 \cdot 3$ & 30.2 & $32 \cdot 5$ & 34.6 & 36.8 & \\
\hline Trade balance & $\$ 84 \mathrm{~b} 1$ & $-57 \cdot 7$ & $-53 \cdot 7$ & -46.6 & $-35 \cdot 9$ & $-24 \cdot 3$ & -14 \\
\hline U.S. current a/c & $\$ 84 b 1$ & $-34 \cdot 7$ & -30.4 & $-25 \cdot 7$ & -16.6 & $-5 \cdot 6$ & \\
\hline Japanese Economy: & & & & & & & \\
\hline GNP gap & $\%$ & $-2 \cdot 9$ & $-2 \cdot 5$ & $-2 \cdot 1$ & -1.8 & $-1 \cdot 5$ & -1 \\
\hline Inflation & & 1.8 & $3 \cdot 3$ & 2.7 & $2 \cdot 3$ & 1.9 & \\
\hline Interest rate & & $1 \cdot 7$ & 1.3 & 0.8 & 0.5 & 0.3 & \\
\hline Exchange rate $($ Yen $/ \$)$ & $\%$ & 3.6 & -0.6 & $-4 \cdot 2$ & -8.0 & -11.6 & -14 \\
\hline Trade balance & $\$ 84 \mathrm{~b} 1$ & 24.0 & $19 \cdot 9$ & $19 \cdot 5$ & 20.2 & $21 \cdot 2$ & 22 \\
\hline Japan current a/c & $\$ 84 b 1$ & 30.4 & 26.1 & 26.5 & $27 \cdot 9$ & $29 \cdot 6$ & 31 \\
\hline OECD Economies: & & & & & & & \\
\hline GNP gap & $\%$ & -4.0 & $-3 \cdot 6$ & $-3 \cdot 3$ & -3.0 & $-2 \cdot 7$ & -2 \\
\hline Inflation & & 6.6 & 8.1 & 7.4 & 6.9 & 6.3 & \\
\hline Interest rate & & 7.6 & $7 \cdot 2$ & 6.8 & 6.6 & 6.4 & \\
\hline Trade balance $(\$ 84)$ & $\$ 84 \mathrm{~b} 1$ & $-12 \cdot 1$ & $-19 \cdot 5$ & -16.6 & $-10 \cdot 1$ & -2.0 & \\
\hline OECD current a/c (\$) & $\$ 84 \mathrm{~b} 1$ & $-22 \cdot 2$ & $-35 \cdot 7$ & $-35 \cdot 7$ & $-32 \cdot 2$ & $-27 \cdot 0$ & -22 \\
\hline Bilateral Trade ( $\%$ U.S. GN) & P): & & & & & & \\
\hline U.S. net exports to Japan & $\begin{array}{l}\% \\
\$ 84 \mathrm{bl}\end{array}$ & $\begin{array}{r}-0.8 \\
-28.5\end{array}$ & $\begin{array}{r}-0.7 \\
-27 \cdot 3\end{array}$ & $\begin{array}{r}-0.7 \\
-26.3\end{array}$ & $\begin{array}{r}-0.6 \\
-25.0\end{array}$ & $\begin{array}{r}-0.6 \\
-23.7\end{array}$ & $\begin{array}{r}-0 \\
-22\end{array}$ \\
\hline U.S. net exports to OECD & $\begin{array}{l}\% \\
\$ 84 \mathrm{bl}\end{array}$ & $\begin{array}{l}-0.1 \\
-4.6\end{array}$ & $\begin{array}{r}0.0 \\
-0.5\end{array}$ & $\begin{array}{l}0.1 \\
2.9\end{array}$ & $\begin{array}{l}0.2 \\
7.1\end{array}$ & $\begin{array}{r}0.3 \\
11.2\end{array}$ & $\begin{array}{r}0 \\
14\end{array}$ \\
\hline Japan net exports to OECD & $\begin{array}{l}\% \\
\$ 84 \mathrm{bl}\end{array}$ & $\begin{array}{r}0.4 \\
13.2\end{array}$ & $\begin{array}{r}0.4 \\
13.2\end{array}$ & $\begin{array}{r}0.3 \\
13.1\end{array}$ & $\begin{array}{r}0.3 \\
13.0\end{array}$ & $\begin{array}{r}0.3 \\
12.8\end{array}$ & \\
\hline
\end{tabular}


little international spillover.

Policy coordination in the face of the baseline has several attractive features. Japan has a non-inflationary reduction in the output gap and ROECD has a large reduction in the output gap with a small rise in inflation due to the fact that their monetary expansions are occurring in the context of currency appreciation, with the currency appreciation coming mainly from the U.S. fiscal contraction. The output gap in the U.S. initially rises, but is lower during 1986-88. There is also a small rise in inflation coming from the currency depreciation. World interest rates are lowered and the global trade imbalances are substantially reduced. The main message of this simulation is that given the utility functions specified above, all of the countries should respond with a monetary expansion to the sharp budget cuts in the United States. Also, Japan and the ROECD may be well placed now for modest fiscal expansions of their own.

\section{SUMMARY OF RESULTS}

It is worthwhile to enumerate briefly the major results of the simulation study. As in the paper, these may be divided into three sections: the effects of policy changes; the projection for adjustment in the next 5 years; and the role for policy coordination in the current economic environment. Effects of Policy Changes:

1. For both the U.S. and Japan, a fiscal expansion raises output, worsens the current account balance and causes an exchange rate appreciation. A shift 
in fiscal stance by the U.S. equal to $4 \%$ of GNP expansion, and by Japan of $2 \%$ of GISP contraction (the approximate magnitudes of change since 1981), are calculated to have the following effects in 1984 ( $\$$ billion):

$\begin{array}{lrr} & \text { U.S. } & \text { Japan } \\ & -77.8 & +28.8 \\ \text { Current Account } & -16.0 & +16.0 \\ \text { Bilateral Trade Balance } & 20.8 & -20.8\end{array}$

Thus, the fiscal changes alone can explain the bulk of the worsening U.S. current account deficit, the improvement of Japan's current account balance, and the appreciation of the dollar relative to the Yen since 1980 . These calculations may underestimate the bilateral effects. With a higher price elasticity $(2.5$ vs. 1.5$)$ for U.S. imports from Japan we find

$\begin{array}{lrr} & \text { U.S. } & \text { Japan } \\ \text { Current Account } & -80.0 & +31.6 \\ \text { Bilateral Trade Balance } & -21.4 & +21.4 \\ \text { Yen } \$ \text { \$ } \% \text { Change }) & 16.6 & -16.6\end{array}$

2. The liberalization of the Yen in international financial markets has significant ramifications for the operation of fiscal policy. Comparing the case of low asset substitutability between the Yen and $\$$ (Table 12), with the case of high substitutability (Table 6), we find that high substitutability:

a) reduces the fiscal multiplier on output;

b) causes the Yen to appreciate rather than depreciate;

c) causes Japanese fiscal expansion to worsen the external balance rather than improve the external balance;

d) causes fiscal expansion to be positively rather than negatively 
transmitted to U.S. GNP and to the U.S. external balance.

3. Fiscal policy is positively transmitted to the other country, since it causes a currency appreciation in the country undertaking the expansion.

4. Monetary expansion is effective in raising output in both economies. Per unit increase of GNP, monetary policy is more inflationary than fiscal policy, and is less adverse for the external balance. These differences result primarily from the fact that fiscal expansion causes an exchange rate appreciation, while monetary policy causes an exchange rate depreciation.

5. Monetary policy changes are not transmitted significantly into foreign GNP, since movements in the exchange rate effectively insulate the foreign economy from the policy change.

6. A discriminatory tariff increase in the U.S. on Japanese goods would cause a significant contraction in Japan, a sharp Yen depreciation, and a rise in inflation in Japan. In the U.S. the policy would cause a dollar appreciation against the Yen and the Ecu; an improvement in the trade balance against Japan, but a significant worsening in the trade balance against the rest of the OECD. Note that the simulation (Table 9) assumes that the tariff change is revenue neutral. The U.S. current account surplus would improve more if the tariff revenues were used to raise overall taxes.

7. With retaliation from Japan (shown in Table 10), the improvement in the U.S. current account balance from a tariff is almost completely eliminated. 8. An oil price shock is highly stagflationary throughout the OECD, with the 
most extreme effects felt in Japan. The Yen depreciates against both the $\$$ and Ecu after an oil price increase.

Projections for Adjustment in the Next Five Years:

9. A gradual policy shift in the U.S. towards fiscal contraction and monetary expansion (Table 14) would:

a) improve the U.S. current account by $\$ 50$ billion (1984 $\$$ ) by 1987;

b) raise U.S. inflation by about $3 / 4$ of 1 percentage point;

c) reduce output abroad, in Japan and ROECD.

10. The contractionary effects of the U.S. policy shift could be of set by modest fiscal expansion in both Japan and ROECD (shown in Table 15). Role For Policy Coordination:

11. In comparing the optimal cooperative path for policy in each country with the baseline, optimal policies would call for:

a) greater U.S. fiscal contraction

b) greater Japanese and ROECD fiscal expansions

c) a generalized monetary expansion

For the utility functions specified we find

Optimal Cooperative

$$
\text { U.S. Japan } \underline{\text { ROECD }}
$$

(Average 1984-89)

Minus Baseline

Fiscal Policy

Budget Deficit

$\begin{array}{llll}(\% \text { of own country GNP) } & -3.0 & 1.4 & 1.2\end{array}$


$-46-$

Appendix A

Five Region Model of the World Economy

U.S. Equations

$$
\begin{aligned}
& Q^{U}=D^{U}+G^{U}+\left(C_{U}^{O}+C_{U}^{J}+C_{U}^{L}+C_{U}^{P}\right)-\left(\Lambda^{O} C_{O}^{U}+\Lambda^{J} C_{J}^{U}+\Lambda^{L} C_{L}^{U}+\Lambda_{C} C_{P}^{U}\right) \\
& \Lambda^{\mathrm{O}}=\mathrm{P}^{\mathrm{O}} \mathrm{E}^{\mathrm{O}} / \mathrm{P}^{\mathrm{U}} \\
& \Lambda^{J}=P^{J} E^{J} / P^{U} \\
& \Lambda^{\mathrm{L}}=\mathrm{P}^{\mathrm{L}} / \mathrm{P}^{\mathrm{U}} \\
& \Lambda^{\mathrm{P}}=\mathrm{P}^{\mathrm{P}} / \mathrm{P}^{\mathrm{U}} \\
& D^{U}=(1-S)\left(Q^{U}-T^{U}\right)-v r^{U}+\delta H^{U} \\
& H^{U}=B^{U}+A_{L}^{U}-A_{U}^{O}-A_{U}^{P}-A_{U}^{J} \\
& B_{t+1}^{U}=\left(B_{t}^{U}+D E F{ }_{t}^{U}\right) /(1+n) \\
& D E F=G^{U}+r_{B}^{U}-v^{U} B_{L}^{U}-T^{U} \\
& M^{U} / P^{U}=Q^{U \phi}\left(1+i^{U}\right)^{-B} \\
& i_{t}^{U}=r_{t}^{U}+\pi_{t+1}^{U} \\
& v_{t}^{U}=.13 r_{t}^{U}+.82 v_{t-1}^{U} \\
& { }_{t+1}^{U}=\left(P_{t+1}^{U}-P_{t}^{U}\right) / P_{t}^{U} \\
& \pi_{t+1}^{C U}=\left(P_{t+1}^{C U}-P_{t}^{C U}\right) / P_{t}^{C U} \\
& \pi_{t+1}^{U}=\pi_{t}^{C U}+\Omega Q_{t}^{U}+\tau\left(Q_{t}^{U}-Q_{t-1}^{U}\right)
\end{aligned}
$$


$-47-$

$$
\begin{aligned}
& P^{C U}=\left(P^{U}\right)^{\gamma_{1}}\left(P^{O} E^{O}\right)^{\gamma_{2}}\left(P^{L}\right)^{\gamma_{3}}\left(P^{J} E^{J}\right)^{\gamma_{4}}\left(P^{P}\right)^{\left(1-\gamma_{1}-\gamma_{2}-\gamma_{3}-\gamma_{4}\right)} \\
& C_{0}^{U}=\alpha_{0}\left(D^{U}+G^{U}\right)\left(\Lambda^{O}\right)^{-1.5} \\
& C_{L}^{U}=\alpha_{1}\left(D^{U}+G^{U}\right)\left(\Lambda^{L}\right)^{-1.0} \\
& C_{P}^{U}=\alpha_{2}\left(D^{U}+G^{U}\right)\left(\Lambda^{P}\right)^{-0.2} \\
& C_{J}^{U}=\alpha_{3}\left(D^{U}+G^{U}\right)\left(\Lambda^{J}\right)^{-1 \cdot 5} \\
& T B^{U}=\left(C_{U}^{O}+C_{U}^{L}+C_{U}^{P}+C_{U}^{J}\right)-\left(C_{0}^{U} \Lambda^{O}+C_{L}^{U} \Lambda^{L}+C_{P}^{U} \Lambda^{P}+C_{J}^{U} \Lambda^{J}\right)
\end{aligned}
$$

Japan Equations

$$
\begin{aligned}
& Q^{J}=D^{J}+G^{J}+\left(C_{J}^{U}+C_{J}^{O}+C_{J}^{L}+C_{J}^{P}\right)-\left(C_{U}^{J}+C_{0}^{J} \Lambda^{O}+C_{L}^{J} \Lambda^{L}+C_{P}^{J} \Lambda^{P}\right) / \Lambda^{J} \\
& D^{J}=\left(1-s^{J}\right)\left(Q^{J}-T^{J}\right)-v r^{J}+\delta H^{J} \\
& H^{J}=B^{J}+A_{J}^{J} / \Lambda^{J}+A_{L J}^{J}+A_{L U}^{J} / \Lambda^{J}-A_{J}^{P} \\
& B_{t+1}^{J}=\left(B_{t}^{J}+D E F_{t}^{J}\right) /(I+n) \\
& D E F^{J}=G^{J}+r_{B}^{J}-v_{B_{L}^{J}}^{J}-T^{J} \\
& M^{J} / P^{J}=Q^{J \phi}(1+i)^{J}-B \\
& i_{t}^{J}=r_{t}^{J}+\pi_{t+1}^{J} \\
& v_{t}^{J}=.82 v_{t-1}^{J}+\cdot 13 r_{t}^{J} \\
& \pi_{t+1}^{J}=\left(P_{t+1}^{J}-P_{t}^{J}\right) / P_{t}^{J} \\
& \pi_{t+1}^{C J}=\left(P_{t+1}^{C J}-P_{t}^{C J}\right) / P_{t}^{C J}
\end{aligned}
$$




$$
\begin{aligned}
& \pi_{t+1}^{\mathrm{J}}=\pi_{t}^{C J}+\Omega Q_{t}^{J}+\tau\left(Q_{t}^{J}-Q_{t-1}^{J}\right) \\
& P^{C J}=\left(P^{J}\right)^{\gamma_{5}}\left(P^{U} / E^{J}\right)^{\gamma} 6\left(P_{E^{O} / E^{J}}\right)^{\gamma_{7}}\left(P^{L} / E^{J}\right)^{\gamma_{8}}\left(P^{P} / E^{J}\right)^{\left(1-\gamma_{5}-\gamma_{6}-\gamma_{7}-\gamma_{8}\right)} \\
& C_{U}^{J}=\alpha_{4}\left(D^{J}+G^{J}\right)\left(\Lambda^{J}\right)^{1.5} \\
& C_{0}^{J}=\alpha_{5}\left(D^{J}+G^{J}\right)\left(\Lambda^{0} / \Lambda^{J}\right)^{-1.5} \\
& \mathrm{C}_{\mathrm{L}}^{\mathrm{J}}=\alpha_{6}\left(\mathrm{D}^{\mathrm{J}}+\mathrm{G}^{\mathrm{J}}\right)\left(\Lambda^{\mathrm{L}} / \Lambda^{\mathrm{J}}\right)-1.0 \\
& C_{P}^{J}=a_{7}\left(D^{J}+G^{J}\right)\left(\Lambda^{P} / \Lambda^{J}\right)^{-0.2}
\end{aligned}
$$

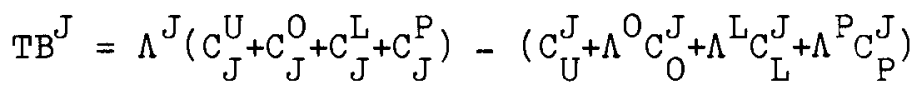

$$
\begin{aligned}
& A_{U t+1}^{J}=\left(A_{U t}^{J}+C A_{t}^{J}\right) /(1+n)-1\left(A_{L J t+1}^{J} \Lambda_{t}^{J}+A_{L U t+1}^{J}+B_{L t+1}^{J} \Lambda_{t}^{J}-A_{J t+1}^{P} \Lambda_{t}^{J}\right) \\
& \text { - } \left.\left(A_{L J t}^{J} \Lambda_{t}^{J}+A_{L U t}^{J}+B_{L t}^{J} \Lambda_{t}^{J}-A_{J t}^{P} \Lambda_{t}^{J}\right) /(1+n)\right] \\
& C A^{J}=T^{J}+r^{U}\left(A_{U}^{J}+A_{L U}^{J}\right)+r^{J} \Lambda^{J} A_{L J}^{J}+v^{J} \Lambda^{J} B_{L}^{J}-r^{J} \Lambda^{J} A_{J}^{P} \\
& \left(A_{U t}^{J}+A_{L U t}^{J}\right) / \Lambda_{t}^{J}=\sigma^{J}\left[r_{t}^{U}-r_{t}^{J}-\left(\Lambda_{t+1}^{J}-\Lambda_{t}^{J}\right) / \Lambda_{t}^{J}\right]+\theta H_{t}^{J}
\end{aligned}
$$

\section{ROECD Equations}

$$
\begin{aligned}
& Q^{0}=D^{O}+G^{O}+\left(C_{0}^{U}+C_{0}^{L}+C_{0}^{P}+C_{0}^{J}\right)-\left(C_{U}^{O}+C_{J}^{O} \Lambda^{J}+C_{L}^{O} \Lambda^{L}+C_{P}^{O} \Lambda^{P}\right) / \Lambda^{O} \\
& D^{0}=(1-s)\left(Q^{O}-T^{O}\right)-v r^{O}+\delta H^{O} \\
& H^{0}=B^{0}+A_{U}^{0} / \Lambda^{0}+A_{L}^{0}-A_{O}^{P} / \Lambda^{0} \\
& B_{t+1}^{0}=\left(B_{t}^{O}+D E F_{t}^{O}\right) /(1+n) \\
& D E F^{0}=G^{0}+r^{O} B^{0}-V^{O} B_{L}^{O}-T^{0}
\end{aligned}
$$




$$
\begin{aligned}
& M^{O} / P^{O}=Q^{O \phi}\left(1+i^{0}\right)^{-B} \\
& i_{t}^{0}=r_{t}^{0}+\pi_{t+1}^{0} \\
& v_{t}^{0}=.13 r_{t}^{0}+.82 v_{t-1}^{0} \\
& \pi_{t+1}^{0}=\left(P_{t+1}^{0}-P_{t}^{0}\right) / P_{t}^{0} \\
& \pi_{t+1}^{\mathrm{CO}}=\left(\mathrm{P}_{\mathrm{t}+1}^{\mathrm{CO}}-\mathrm{P}_{t}^{\mathrm{CO}}\right) / \mathrm{P}_{\mathrm{t}}^{\mathrm{CO}} \\
& \pi_{t+1}^{0}=\pi_{t}^{C O}+\Omega Q_{t}^{0}+\tau\left(Q_{t}^{0}-Q_{t-1}^{0}\right) \\
& \left.P^{C O}=\left(P^{0}\right)^{\gamma}{ }^{\gamma}\left(P^{U} / E^{0}\right)^{\gamma} 10\left(P^{L} / E^{0}\right)^{\gamma} 11\left(P^{J} E^{J} / E^{0}\right)^{\gamma} 12\left(P^{P} / E^{0}\right)^{(1-\gamma} 9^{-\gamma} 10^{-\gamma} 11^{-\gamma} 12\right) \\
& C_{U}^{0}=\alpha_{8}\left(D^{0}+G^{0}\right)\left(\Lambda^{0}\right)^{1.5} \\
& C_{J}^{0}=\alpha_{9}\left(D^{0}+G^{0}\right)\left(\Lambda^{J} / \Lambda^{0}\right)^{-1 \cdot 5} \\
& C_{L}^{0}=\alpha_{10}\left(D^{0}+G^{0}\right)\left(\Lambda^{L} / \Lambda^{0}\right)^{-1 \cdot 0} \\
& C_{P}^{0}=\alpha_{11}\left(D^{0}+G^{0}\right)\left(\Lambda^{P} / \Lambda^{0}\right)^{-0.2} \\
& T B^{O}=\left(C_{0}^{U}+C_{0}^{L}+C_{0}^{P}+C_{0}^{J}\right)-\left(C_{U}^{O}+C_{J}^{O} \Lambda^{J}+C_{L}^{O} \Lambda^{L}+C_{P}^{O} \Lambda^{P}\right) / \Lambda^{O} \\
& A_{U t+1}^{0}=\left(A_{U t}^{0}+C A_{t}^{0}\right) /(1+n)-\left[\left(A_{L}^{0}+B_{L}^{0}\right)_{t+1} \Lambda_{t}^{0}-\left(A_{L}^{0}+B_{L}^{0}\right) \Lambda_{t}^{0} /(1+n)-A_{0 t+1}^{P}+A_{O t}^{P} /(1+n)\right] \\
& C A^{O}=\left(A_{U}^{O}-A_{0}^{P}\right) r^{U}+\left(A_{L}^{O} \Lambda^{0}\right) r^{O}+\left(B_{L}^{O} \Lambda^{O}\right) v^{O}+T_{B}^{0} \Lambda^{O} \\
& \left(A_{U}^{0}-A_{0}^{P}\right)_{t} / \Lambda_{t}^{0}=\sigma\left[r_{t}^{U}-r_{t}^{0}-\left(\Lambda_{t+1}^{0}-\Lambda_{t}^{0}\right) / \Lambda_{t}^{0}\right]+\theta H_{t}^{0}
\end{aligned}
$$


$-50-$

LDC Equations

$$
\begin{aligned}
& \left.P^{I}=\left(P^{U}\right)^{n}{ }^{n}\left(P_{E}^{O}\right)^{O}\right)^{n_{2}}\left(P^{J} E^{J}\right)^{n_{3}}\left(P^{P}\right)^{\left(1-n_{1}-n_{2}-n_{3}\right)}\left(C_{L}^{U}+C_{L}^{O}+C_{L}^{P}+C_{L}^{J}\right)^{\gamma_{L}} \\
& C_{U}^{L}=n_{1}\left(C_{U}^{L}+\Lambda^{O} C_{O}^{L}+\Lambda^{P} C_{P}^{L}+\Lambda^{J} C_{J}^{L}\right) \\
& C_{0}^{L}=n_{2}\left(C_{U}^{L}+\Lambda^{O} C_{0}^{L}+\Lambda^{P} C_{P}^{L}+\Lambda^{J} C_{J}^{L}\right) / \Lambda^{O} \\
& C_{J}^{L}=n_{3}\left(C_{U}^{L}+\Lambda^{O} C_{O}^{L}+\Lambda^{P} C_{P}^{L}+\Lambda^{J} C_{J}^{L}\right) / \Lambda^{J} \\
& C_{P}^{L}=\left(1-n_{1}-n_{2}-n_{3}\right)\left(C_{U}^{L}+\Lambda^{O} C_{0}^{L}+\Lambda^{P} C_{P}^{L}+\Lambda^{J} C_{J}^{L}\right) / \Lambda^{P} \\
& T B^{L}=\Lambda^{L}\left(C_{L}^{U}+C_{L}^{O}+C_{L}^{P}+C_{L}^{J}\right)-C_{U}^{L}-\Lambda^{O} C_{0}^{L}-\Lambda^{P} C_{P}^{L}-\Lambda^{J} C_{J}^{L} \\
& \mathrm{CA}_{t}^{\mathrm{L}}=\omega C \mathrm{~A}_{\mathrm{t}-1}^{\mathrm{L}}+\varepsilon\left\{\mathrm{DEBT}_{\mathrm{t}}-\xi \Lambda_{t}^{\mathrm{L}}\left(\mathrm{C}_{\mathrm{Lt}}^{\mathrm{O}}+\mathrm{C}_{\mathrm{Lt}}^{\mathrm{U}}+\mathrm{C}_{\mathrm{Lt}}^{\mathrm{P}}+\mathrm{C}_{\mathrm{Lt}}^{\mathrm{J}}\right)[1+\mathrm{n}(1-\omega) / \varepsilon]\right\} \\
& D_{t} B_{t}=A_{L}^{U}+\left(A_{L}^{O} \Lambda^{O}\right)+A_{L}^{P}+B_{L}^{U}+\left(B_{L}^{O} \Lambda^{O}\right)+A_{L U}^{J}+A_{L J}^{J} \Lambda^{J}+B_{L}^{J} \Lambda^{J} \\
& B_{L t+1}^{U}=B_{L t}^{U}+\cdot 1\left[A_{L t+1}^{U}(I+n)-A_{L t}^{U}\right] \\
& B_{L t+1}^{O}=B_{L t}^{O}+\cdot 1\left[A_{L t+1}^{O}(1+n)-A_{L t}^{O}\right] \\
& \Lambda_{t}^{J} B_{L t+1}^{J}=\Lambda_{t}^{J} B_{L t}^{J}+\cdot 1\left[\left(A_{L J t+1}^{J} \Lambda_{t}^{J}+A_{L U t+1}^{J}\right)(1+n)-\left(A_{L J t}^{J} \Lambda_{t}^{J}+A_{L U t}^{J}\right)\right] \\
& A_{L t+1}^{O} \Lambda_{t}^{O}=\left\{a _ { 1 } \left[\left(A_{L t+1}^{U}+A_{L t+1}^{O} \Lambda_{t}^{O}+A_{L t+1}^{P}+A_{L J t+1}^{J} \Lambda_{t}^{J}+A_{L U t+1}^{J}\right)(1+n)\right.\right. \\
& \left.\left.-\left(A_{L t}^{U}+A_{L t}^{O} \Lambda_{t}^{O}+A_{L t}^{P}+A_{L J t}^{J} \Lambda_{t}^{J}+A_{L U t}^{J}\right)\right]+A_{L t}^{O} \Lambda_{t}^{O}\right\} /(1+n) \\
& A_{L t+1}^{P}=\left\{a_{2}\left[\left(A_{L t+1}^{U}+A_{L t+1}^{0} \Lambda_{t}^{O}+A_{L t+1}^{P}+A_{L J t+1}^{J} \Lambda_{t}^{J}+A_{L U t+1}^{J}\right)\right)(1+n)\right. \\
& \left.\left.-\left(A_{L t}^{U}+A_{L t}^{0} \Lambda_{t}^{0}+A_{L t}^{P}+A_{L J t}^{J} \Lambda_{t}^{J}+A_{L U t}^{J}\right)\right]+A_{L t}^{P}\right\} /(1+n) \\
& A_{L J t+1}^{J} \Lambda_{t}^{J}=\left\{a _ { 3 } \left[\left(A_{L t+1}^{U}+A_{L J t+1}^{J} \Lambda_{t}^{J}+A_{L U t+1}^{J}+A_{L t+1}^{O} \Lambda_{t}^{O}+A_{L t+1}^{P}\right)(1+n)\right.\right. \\
& \left.\left.-\left(A_{L t}^{U}+A_{L J t}^{J} \Lambda_{t}^{J}+A_{L U t}^{J}+A_{L t}^{0} \Lambda_{t}^{0}+A_{L t}^{P}\right)\right]+A_{L J t}^{J} \Lambda_{t}^{J}\right\} /(1+n)
\end{aligned}
$$


$-51-$

$$
\begin{aligned}
A_{L U t+1}^{J} & =\left\{a _ { L } \left[\left(A_{L t+1}^{U}+A_{L J t+1}^{J} \Lambda_{t}^{J}+A_{L U t+1}^{J}+A_{L t+1}^{0} \Lambda_{t}^{0}+A_{L t+1}^{P}\right)(1+n)\right.\right. \\
& \left.\left.-\left(A_{L t}^{U}+A_{L J t}^{J} \Lambda_{t}^{J}+A_{L U t}^{J}+A_{L t}^{0} \Lambda_{t}^{0}+A_{L t}^{P}\right)\right]+A_{L U t}^{J}\right\} /(1+n) \\
A_{L t+1}^{U} & =\left(A_{L t}^{U}+C A_{t}^{L}\right) /(1+n)-\left[\left(A_{L J t+1}^{J} \Lambda_{t}^{J}+A_{L U t+1}^{J}+A_{L t+1}^{0} \Lambda_{t}^{0}+A_{L t+1}^{P}+B_{L t+1}^{U}+B_{L t+1}^{J} \Lambda_{t}^{J}+B_{L t+1}^{O} \Lambda_{t}^{0}\right)\right. \\
& \left.-\left(A_{L J t}^{J} \Lambda_{t}^{J}+A_{L U t}^{J}+A_{L t}^{O} \Lambda_{t}^{O}+A_{L t}^{P}+B_{L t}^{U}+B_{L t}^{J} \Lambda_{t}^{J}+B_{L t}^{0} \Lambda_{t}^{0}\right) /(1+n)\right]
\end{aligned}
$$

OPEC Equations

$$
\begin{aligned}
& P^{P}=\left(P^{U}\right)^{n_{4}}\left(P^{0} E^{0}\right)^{n_{5}}\left(P^{J} E^{J}\right)^{n_{\sigma}}\left(P^{L}\right)^{\left(1-n_{4}-n_{5}-n_{6}\right)}\left(C_{P}^{U}+C_{P}^{O}+C_{P}^{L}+C_{P}^{J}\right)^{\gamma_{P}} \\
& C_{U}^{P}=n_{4}\left(C_{U}^{P}+\Lambda{ }^{O}{ }_{0}^{P}+\Lambda{ }^{L} C_{L}^{P}+\Lambda^{J} C_{J}^{P}\right) \\
& C_{0}^{P}=\eta_{5}\left(C_{U}^{P}+\Lambda C_{0}^{O}+\Lambda^{L} C_{L}^{P}+\Lambda^{J} C_{J}^{P}\right) / \Lambda^{0} \\
& C_{J}^{P}=\eta_{6}\left(C_{U}^{P}+\Lambda C_{0}^{O^{P}}+\Lambda^{L} C_{L}^{P}+\Lambda^{J} C_{J}^{P}\right) / \Lambda^{J} \\
& C_{L}^{P}=\left(1-n_{4}-n_{5}-n_{6}\right)\left(C_{U}^{P}+\Lambda^{O} C_{0}^{P}+\Lambda^{L} C_{L}^{P}+\Lambda^{J} C_{J}^{P}\right) / \Lambda^{L} \\
& H^{P}=A_{U}^{P}+A_{0}^{P}+A_{L}^{P}+A_{J}^{P} \Lambda^{J} \\
& { }^{P B} P=\Lambda^{P}\left(C_{P}^{U}+C_{P}^{O}+C_{P}^{L}+C_{P}^{J}\right)-C_{U}^{P}-\Lambda^{0} C_{O}^{P}-\Lambda^{L} C_{L}^{P}-\Lambda^{J} C_{J}^{P} \\
& \mathrm{CA}_{t}^{\mathrm{P}}=\zeta\left[\psi\left(\mathrm{C}_{\mathrm{P}}^{\mathrm{U}}+\mathrm{C}_{\mathrm{P}}^{\mathrm{O}}+\mathrm{C}_{\mathrm{P}}^{\mathrm{L}}+\mathrm{C}_{\mathrm{P}}^{\mathrm{J}}\right)_{t}\left(\mathrm{P}^{\mathrm{P}} / \mathrm{P}^{\mathrm{U}}\right)_{t}-\mathrm{H}_{t-1}^{\mathrm{P}}\right]+\mathrm{nH}_{t-1}^{\mathrm{P}} \\
& A_{U t+1}^{P}=\left(A_{U t}^{P}+C A_{t}^{P}\right) /(1+n)-\left[\left(A_{0}^{P}+A_{L}^{P}\right)_{t+1}+A_{J t+1}^{P} \Lambda_{t}^{J}-\left(A_{0}^{P}+A_{L}^{P}+A_{J}^{P} \Lambda^{J}\right) /(1+n)\right] \\
& A_{0 t+1}^{P}=\left\{b_{1}\left[\left(A_{U}^{P}+A_{0}^{P}+A_{L}^{P}+A_{J}^{P} \Lambda_{t}^{J}\right)_{t+1}(1+n)-\left(A_{U}^{P}+A_{0}^{P}+A_{L}^{P}+A_{J}^{P} \Lambda_{t}^{P}\right)_{t}\right]+A_{0 t}^{P}\right\} /(1+n) \\
& A_{J t+1}^{P} \Lambda_{t}^{J}=\left\{b_{2}\left[\left(A_{U}^{P}+A_{0}^{P}+A_{L}^{P}+A_{J}^{P} \Lambda_{t}^{J}\right)_{t+1}(1+n)-\left(A_{U}^{P}+A_{0}^{P}+A_{L}^{P}+A_{J}^{P} \Lambda^{J}\right)_{t}\right]+A_{J t}^{P} \Lambda_{t}^{J}\right\} /(1+n)
\end{aligned}
$$


Definitions

A

Claims on country $j$ held by private creditors in country $i$

$B_{j}^{i}$

Claims on country $j$ held by official creditors in country $i$

$B^{i} \quad$ Government debt of country $i$

$\mathrm{C}_{j}^{i} \quad$ Consumption by country $i$ of the output of country $j$

CA Current account

D Domestic absorption

DEBT LDC debt

DEF Government deficit

$\mathrm{E}^{\mathrm{O}} \quad$ Exchange rate $(\$ / \mathrm{ECU})$

$\mathrm{E}^{J} \quad$ Exchange rate (\$/yen)

G Government Expenditure

$\mathrm{H} \quad$ Real Financial Wealth

i Nominal interest rate

M Nominal money supply

n Growth rate

$\mathrm{P}^{i} \quad$ Price level of country $i$ goods

$\mathrm{P}^{\mathrm{C}} \quad$ Consumer price index

$\pi_{t} \quad$ Domestic price inflatio

$\pi_{t}^{C} \quad$ Consumer price inflation 
Gross domestic product

r

Real interest rate

Taxes

TB

Trade Balance

$\mathrm{v}$

Concessional real interest rate

$\Lambda$

Real exchange rate 
Table AI

Parameter Values

$$
\begin{aligned}
& S=0.3 \\
& S^{J}=0.5 \\
& \nu=0.2 \\
& \delta=0.1 \\
& n=0.03 \\
& \phi=0.8 \\
& \beta=0.9 \\
& s_{3}=0.2 \\
& t=0.2 \\
& \gamma_{1}=0.921 \\
& \gamma_{2}=0.034 \\
& \gamma_{3}=0.024 \\
& \gamma_{4}=0.013 \\
& \gamma_{5}=0.899 \\
& \gamma_{6}=0.020 \\
& \gamma_{7}=0.017 \\
& \gamma_{8}=0.026 \\
& \gamma_{9}=0.930 \\
& \gamma_{10}=0.024 \\
& \gamma_{1}=0.90
\end{aligned}
$$$$
\gamma_{11}=0.022
$$$$
r_{12}=0.008
$$$$
\alpha_{0}=0.034
$$$$
\alpha_{1}=0.024
$$$$
\alpha_{2}=0.008
$$$$
\alpha_{3}=0.013
$$$$
\alpha_{4}=0.020
$$$$
\alpha_{5}=0.017
$$$$
\alpha_{6}=0.026
$$$$
\alpha_{7}=0.038
$$$$
\alpha_{8}=0.024
$$$$
\alpha_{9}=0.008
$$$$
\alpha_{10}=0.022
$$$$
\alpha_{11}=0.015
$$$$
\sigma=4
$$$$
\sigma^{J}=1
$$$$
n_{2}=0.0353
$$$$
n_{3}=0.145
$$$$
n_{4}=0.092
$$$$
n_{5}=0.323
$$$$
n_{6}=0.109
$$$$
\gamma_{L}=0.5
$$$$
\gamma_{P}=0.5
$$$$
a_{1}=0.110
$$$$
a_{2}=0.230
$$$$
a_{3}=0.010
$$$$
a_{4}=0.130
$$$$
b_{1}=0.226
$$$$
b_{2}=0.070
$$$$
\omega=0.9
$$$$
\varepsilon=0.3
$$$$
\theta=0.5
$$$$
\xi=1.97
$$$$
n_{1}=0.194
$$$$
\psi=1.86
$$ 


\section{Appendix B}

LDC DEBT

Following the same procedures as Sachs and McKibbin (1985), we are able to derive the breakdown of LDC gross debt into type of lender (private or official) and into currency composition (\$US-denominated or Ecu, including Japanese yen). We then subtract the loans by Japan and OPEC to the LDCs from the original values (source: IMF, Ministry of Finance). Note that we assume that all OPEC loans are \$US-denominated and that Japanese loans are divided into three parts: yen-denominated official loans, yen-denominated private loans, and \$US-denominated private loans. The breakdown of net debt (shown in Table BI) is derived by subtracting LDC reserves by currency composition from correspondent loans (source: IMF).

OPEC ASSET HOLDING

Based on data contained in Mattione (1983), we find the breakdown of OPEC investment divided into \$-denominated in LDC, \$-denominated in U.S. and Ecu-denominated investment. In this work we substract the value of OPEC investments in Japan (assumed yen-denominated) (source: Japanese Ministry of Finance and others) from Ecu-denominated investment (given in Table B2).

\section{JAPANESE ASSET HOLDING}

In order to estimate the total amount of Japanese holdings of U.S. assets, we have to pick up the major items in capital flows and calculate the existing stock value on each item. Major items between the U.S. and Japan are securities 
investment (in particular, bonds investment) and long-term and short-term private loans. U.S.-bond investment by Japanese institutional investors (including pension funds and insurance companies), in particular, are expanding rapidly. We estimate the total value of Japanese holding of U.S. assets as $\$ 35$ billion in the end of 1983 (.010 as a share of U.S. GDP).

In order to find the outstanding stock of Japanese government bonds, we take the same assumption as in the ROECD case, that the outstanding stock of Japanese government debt is the same proportion of Japanese GDP as the U.S. stock is of U.S. GDP. 
Table B1: Compositicn of LDC Net Debt

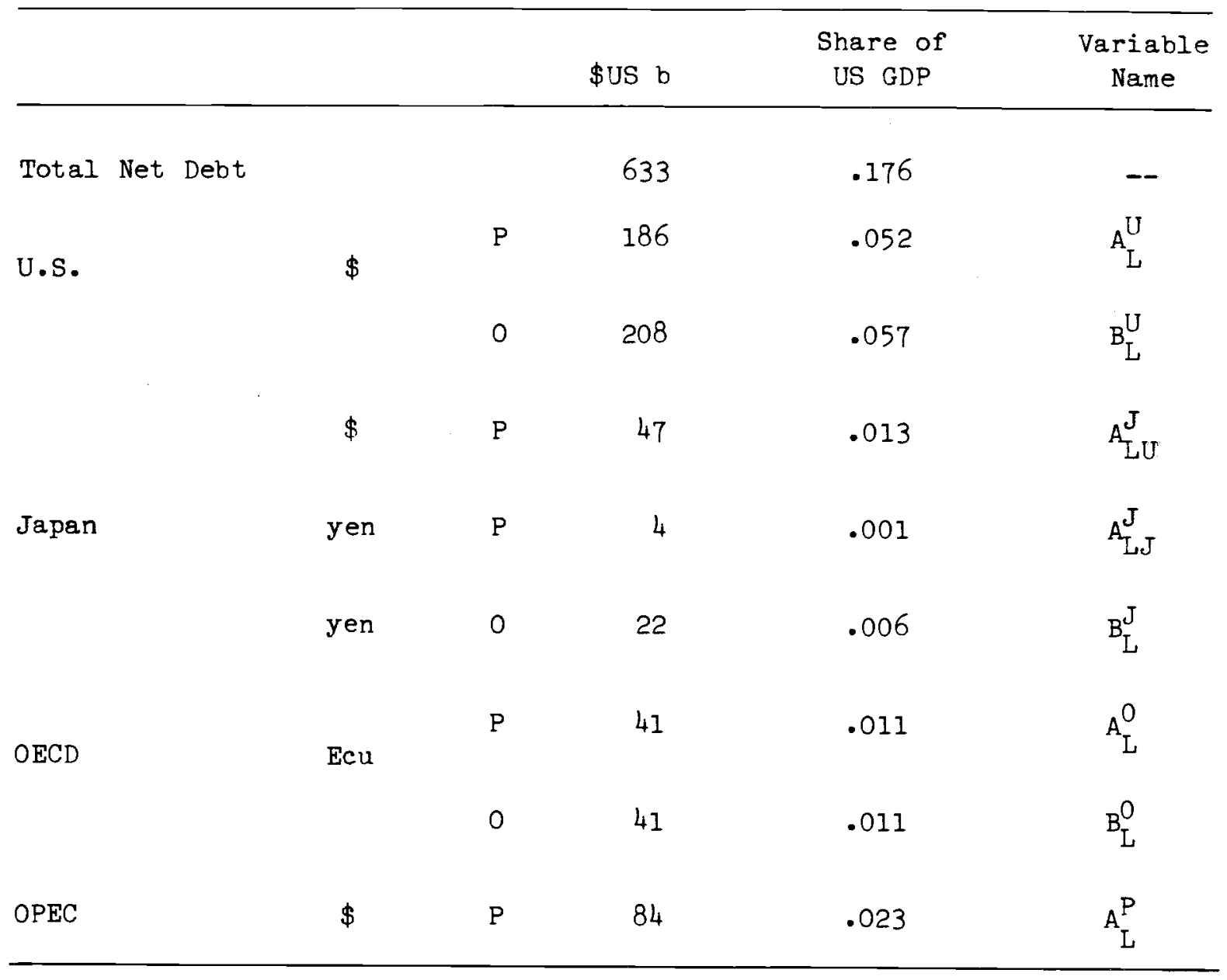

Table B2: OPEC Asset Holding (Beginning of 1983)

\begin{tabular}{|c|c|c|c|c|}
\hline & & $\$$ US b & $\begin{array}{l}\text { Share of } \\
\text { US GDP }\end{array}$ & $\begin{array}{c}\text { Variable } \\
\text { Name }\end{array}$ \\
\hline Total Net & Debt & $377 \cdot 3$ & .116 & $-\infty$ \\
\hline U.S. & $\$$ & 190.1 & .058 & $A_{U}^{P}$ \\
\hline Japan & yen & $27 \cdot 2$ & .008 & $A_{J}^{P}$ \\
\hline OECD & Ecu & 86.0 & .026 & $A_{0}^{P}$ \\
\hline LDC & $\$$ & 74.0 & .023 & $A_{L}^{P}$ \\
\hline
\end{tabular}




\section{$\underline{\text { References }}$}

Fukao M. (1985), "The Effectiveness of Coordinated Intervention," in T. Hosomi and M. Fukao," A Second Look at Foreign Exchange Market Interventions", JCIF Policy Studies Series no 3, April.

Mattione, R. (1983), "OPEC's Investments and the International Financial System," Brookings Discussion Paper in International Economics, No. 6 .

Oudiz, G. and J. Sachs (1984a), "Macroeconomic Policy Coordination Among the Industiral Economies," Brookings Papers on Economic Activity, 1 .

Oudiz, G. and J. Sachs (1985), "International Policy Coordination in Dynamic Macroeconomic Models," in W. Buiter and R. Marston (eds.), International Economic Policy Coordination, CEPR and NBER, by Cambridge University Press.

Sachs, J. and W. McKibbin. (1985), "Macroeconomic Policies in the OECD and LDC External Adjustment," NBER Working Paper Series No. 1534, January.

Sachs, J. (1985), "The Policy Mix and the Dollar: 1985," Brookings Papers on Economic Activity, 1985: 1 (forthcoming). 